\title{
SLUDGE STORAGE LAGOON BIOGAS RECOVERY AND USE
}

\author{
VOLUME 2
}

Energy Task Force

of the Urban Consortium

for Technology Initiatives

\section{CITY OF MEMPHIS}

Richard C. Hackett, Mayor

Prepared by:

Division of Planning and Development

Dexter Muller, Director

Cliff Norville, P.E.

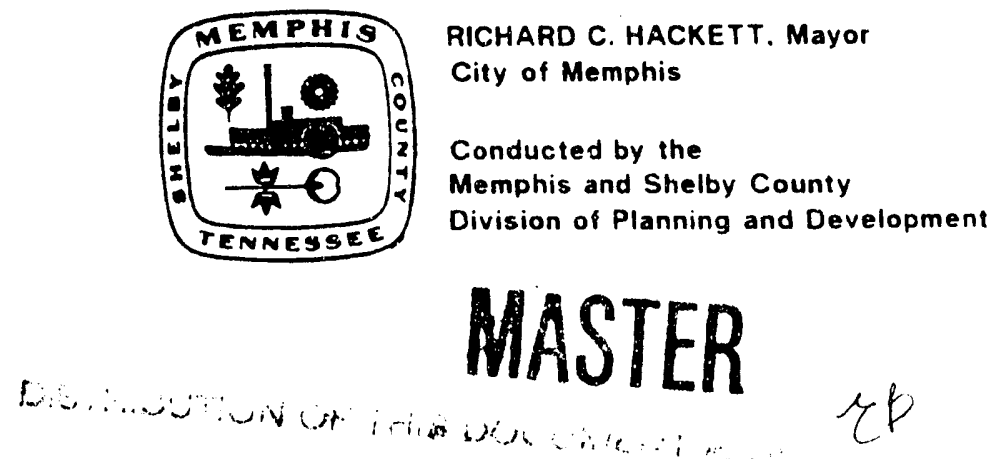




\section{PREFACE}

\section{YEAR 11 ETF PUBLICATION}

The Urban Consortium for Technologies (UC) is composed of over forty of the largest cities and urban counties by population in the United States. The Consortium provides a unique forum to define urban problems common to its member governments and to develop, apply transfer and commercialize technologies and innovative management techniques to address those problems.

The Urban Consortium conducts its work program under the guidance of Task Forces structured according to the functions and concerns of local governments. The Urban Consortium Energy Task Force (UCETF), with a core membership of 20 large cities and counties, was formed in 1979 to help improve urban energy management deci-ion-making through applied research and technology transfer. The UCETF focuses on developing and sharing new approaches and innovative solutions to energy management problems with interested local governments. Projects with similar subjects are organized into Units with each unit managed by a selected Task Force member.

A description of the Units and projects included in the 1990 program are as follows:

\section{ALTERNATIVE VEHICLE FUELS}

Alternative vehicle fuels offer a very strong potential to aid in the reduction of US dependence on foreign oil supplies, with the concomitant benefits of decreased air pollution in urban areas. Local governments can play an instrumental role in realizing this potential through practical applied research and highly visible demonstrations for alternative fuel and technology options. Projects in this topic area place a strong emphasis on the examination of all potential alternate fuels with support from teaming and partnership activities among cities and counties, utilities and other relevant private sector organizations that have matching interests. The 1990 Alternative Vehicle Fuels unit consists of:
Albuquerque, NM -- Alternative Fuel Vehicles in Municipal Dury Cycles
Broward County, FL -. Dual Fuel
Conversion Demonstration
Detroit, MI - Assessment of AFV
Availability to Meet Emergency
Contingency Planning and Long Term
Public Fleet Integration
Denver, CO -- Alternative Fueis and
Transportation Management Associations
Houston, TX -- CNG Fueled Vehicle Comparison
New York, NY -- Alternative Transportation Fuels: Infrastructure Issues

Pittsburgh, PA -- Compressed Natural Gas as an Alternative Vehicle Fuel

San Diego, CA -- Siting Alternative

Fuel Filling and Maintenance Stations

\section{ELECTRICITY MANAGEMENT}

Energy costs can place a severe burden on residents and limit economic growth for both energy-intensive industries and the vital small business sector that provides the majority of today's employment opportunities. Urban governments, therefore, need to have the ability to manage both the use and demand for electricity supplies. The emphases on the 1990 electricity management projects include attention to broad issues of electricity cost as an economic factor in commercial development decisions, procedures for the design of major new public facilities, and the feasibility of emerging decentralized and/or alternative sources of electrical energy. This 1990 unit consists of: 
Chicago, IL -- Central Station DHC

Phase I Feasibility Analysis

Columbus, $\mathrm{OH}$-- Electricity Demand Impacts of New Indoor Air Quality Standards

Dade County, FL -- Global, Automated Urban Government Energy System (GAUGES)

Detroit, MI -- Hydraulic Waste Energy Recovery City of Detroit Water Distribution System

Kansas City, MO --Use of Cogeneration System to Control Electrical Demand

Montgomery County, MD -. Integrated Energy Planning for a New Detention Center

New York, NY -- Strategies to Reduce Electricity Cost in New Commercial Construction

\section{ENERGY，ENVIRONMENT AND ECONOMIC DEVELOPMENT}

Today's urban centers face critical and continuing problems that constrain their ability to provide affordable housing, to reduce congested highways, and to improve air quality, waste management, and economic development. The efficient use of energy and the development of alternate, clean energy resources can help address these broad community problems and contribute significantly to achieve truly sustainable, environmentally responsible, and economically viable communities. This unit, therefore, deals with community problems, from affordable housing to alternate clean energy' resources. Urban strategies to improve energy-sustainability will require attention to both broad based institutional changes, as well as specific projects designed to encourage the application of appropriate technology and community development practices. This 1990 unit consists of:

Phoenix, AZ -- Impact of Heat Islands on Cooling and Environment

Los Angeles, CA -- Heat Island Mitigarion

Pima County, AZ -- Tucson Solar Village

Portland, OR -- The Sustainable City: Phase II
San Jose, CA -- The Sustainable City: Phase II

San Francisco, CA -. The Sustainable City: Phase II

St. Louis, MO -- Pilot Program for

Energy Efficient Mortgages

Washington, DC -- Energy Efficiency

in Public Housing

\section{WASTE MANAGEMENT}

Effective and environmentally sound waste management is a concern of local government that only promises to grow in its significance through the decade. Urban strategies for waste management are evolving into coherent approaches that integrate traditional collection and disposal practices with new emphases on waste source reduction, separation and isolation of hazardous wastes, and practical recycling procedures. This year's unit consists of:

Hennepin County, MN -- Household Hazardous Waste Processing - Phase II

Houston, TX -- Solid Waste Integraied Cost Analysis Model: An Applied Decision Making Tool for Municipalities

Memphis, TN -- Sludge Storage Lagoon Biogas Recovery

New Orleans, LA -- Pyrolysis Disposal of Scrap Tires

San Diego, CA -- Mixed Plastics Recycling

Seattle, WA -- Evaluation of Hazardous Waste Management Programs

Reports from each of these projects are specif-rally designed to aid the transfer of proven experience to other local governments. Readers interested in obtaining any of these reports or further information about the Energy Task Force and the Urban Consortium should contact:

\section{Energy Program}

Public Technology, Inc.

1301 Pennsylvania Avenue, NW

Washington, DC 20004 


\section{ACKNOWLEDGEWMENTS}

This project was the result of a cooperative effort with several divisions of local government contributing toward its successful completion. It is a sincere pleasure to acknowledge and thank them for their efforts.

This project was implemented with grant financing from the U.S. Department of Energy through the Eleventh Year Grant Program of the Urban Consortium Energy Task Force. Technical and project management support was provided by Urban Consortium representatives from Hennepin county and Public Technology, Inc. Project staff members from the Division of Planning and Development of the City of Memphis very much appreciate the generous assistance provided by these organizations.

Mr. Dexter Muller, Director of the Memphis/Shelby County Division of Planning and Development and Urban Consortium Energy Task Force member, served as Project Director. Mr. Cliff Norville, Manager of Energy Management in the Division of Planning and Development, served as Project Manager during implementation of this project.

Project guidance was provided by Mr. Benny Lendermon, Mr. Rodney Eder, Mr. Jerry Collins, Mr. Rodney Thomas, and Mr. Joe Taylor of the Division of Public Works, Mr. John Pontius of the Division of Finance, and Mr. Robert Pepper of the Division of Sanitation. These individuals assisted with project design and implementation activities and merit special acknowledgement for their valuable contributions as project team members. 
Mr. Cliff Norville is the principal author of this report. Editorial assistance was provided by Mr. Muller, Ms. Debra Siniard, Mr. Robert Miller of the Urban Consortium Energy Task Force, and Mr. Matt Korot of Public Technology, Inc. Project Graphics were prepared by Mr. David Walker and his staff. Word-processing tasks were performed by Mrs. Tammy case and Mr. Brian Page, and clerical assistance was provided by Ms. Shirley Davis. 
CONTENTS

Page

CHAPTER 1 - EXECUTIVE SUMMARY

Abstract 1

Project Purpose 2

Report organization 4

CHAPTER 2 - BACKGROUND/PROJECT CONSTRUCTION 7

Review of Sludge Stabilization $\quad 7$

Stiles Wastewater Treatment Plant

Stabilization Process $\quad 8$

Problem Identification $\quad 10$

Proposed Solution $\quad 14$

Construction Procedure 17

Construction Schedule 30

Delays/Obstacles 30

Project Cost Analysis 34

CHAPTER 3 - PERFORMANCE EVALUATION 39

Phase 1 Analysis - Biogas Recovery 39

Phase 2 Analysis - Biogas Utilization 52

CHAPTER 4 - CONCLUSIONS 57

$\begin{array}{ll}\text { Lessons Learned } & 57\end{array}$

$\begin{array}{lc}\text { REFERENCES } & 63\end{array}$ 
No.

Title

Page

1 Memphis Enterprise Zone 12

2 System Diagram 19

3 Influent Inlet Extension 21

4 Modified Truck Dumping Station 22

5 Cover Plan 24

6 Cover Anchor 25

7 Anchor Support Block 26

8 Sludge Pump Canal Detail 27

9 Biogas Venting 29

10 Biogas Building Plan 31

11 Construction Progress Chart 32 
CHAPTER ONE -- EXECUTIVE SUMMARY

\author{
ABSTRACT
}

The City of Memphis has two treatment plants: the T.E. Maxson Wastewater Treatment Plant and the M.C. Stiles wastewater Treatment Plant (SWTP). The SWTP employs two large anaerobic digestion sludge lagoons as part of the overall sludge treatment system. Although these lagoons are effective in concentrating and digesting sludge, they can generate offensive odors. The SWTP uses aerobic digesters to partially stabilize the sludge and help reduce objectionable odors before it enters the lagoons.

The anaerobic digestion of sludge in the lagoons results in the dispersion of a large quantity of biogas into the atmosphere. The city realized that if the lagoons could be covered, the odor problem could be resolved, and at the same time, biogas could be recovered and utilized as a source of energy.

In 1987, the City commissioned ADI International to conduct a feasibility study to evaluate alternative methods of covering the lagoons and recovering and utilizing the biogas. The study recommended that the project be developed in two phases: 1) recovery of the biogas and 2) utilization of the biogas. Phase 1 consists of covering the two lagoons with an insulated membrane to control odor and temperature and collect the biogas. Phase 2 involves one of two 
options. The gas may be piped and sold to a large industry proximate to the lagoons, or the gas may be used to fuel electric generators to produce electricity for operating the wastewater treatment plant.

Phase 1 was found to be economically feasible and offered a unique opportunity for the city to save substantial operating costs at the treatment facility. The results of the feasibility study and the planning for construction of the lagoon covers are described in volume 1. This report follows the construction of the biogas recovery system and evaluates the status of Phase 2.

The Memphis biogas recovery project is the only application in the world where a membrane cover has been used on a municipal wastewater sludge lagoon. It is also the largest lagoon cover system in the world.

PROJECT PURPOSE

The purposes of this project were to evaluate the potential for collecting and using biogas generated by sludge storage lagoons; to facilitate decision-making regarding financing, construction, and operation of the project; and to document the project costs and benefits to the city.

The specific research objectives of this project were to:

* Confirm the conclusions of the preliminary engineering feasibility study;

* Facilitate the decision to proceed with the project;

* Assess the public and private options for financing and operating the system; 
* Document the baseline and fully implemented conditions to allow an accurate assessment of project costs and benefits;

* Prepare a report that summarizes the project and transfers to other communities the evaluation process and the energy recovery technology utilized.

The initial step in the research plan involved a review of the engineering feasibility study to confirm its assumptions and to evaluate the estimated payback based on various financing approaches. The baseline conditions researched and documented were current energy consumption and costs, quantities of sludge stored, environmental conditions, and other pertinent data necessary to quantify eventual costs and benefits. The findings from this research were reporter in Volume 1.

Throughout the design and construction phases, the project staff documented the construction cycle, any changes in the project, and actual costs associated with design and construction. During the first six months of operation, the actual quantities of sludge stored, gas produced, costs of operation, energy consumption, and savings in energy costs were monitored for comparison with the baseline.

The results of this project range from direct economic benefits to operational benefits associated with enhanced communication and cooperation between local governmental agencies. The results include:

1) substantial $n$ 't savings of energy and dollars,

2) enhanced credibility of the newly created Energy Management section of the office of Economic and Resource Development with the local utility company and other governmental agencies, 
3) establishment of a process to scientifically document savings and to better evaluate the actual costs-benefits of energy improvements,

4) resolution of a current problem and productive utilization of a previously wasted resource,

5) improved environmental conditions, and

6) increased local awareness of innovative financing approaches that may be applicable to other energy projects currently under consideration.

REPORT ORGANIZATION

The process used at the wastewater treatment facilities serving Memphis is common to many communities across the country. The intent of this report is to transfer the experiences of the Memphis project to other communities with comparable waste disposal methods. Two years were required to design and construct the project; therefore, this report is presented in two volumes to document progress. Volume 1 provides background information on biogas production from anaerobic digestion and the economic justification for recovery of the biogas. It also describes the project design and construction bid process. Volume 2 is organized in the following manner:

\section{Chapter 1 Executive Summary}

Biogas generated by sludge lagoons causes odors that are a significant public nuisance. Chapter 1 discusses this problem and provides a brief overview of the solution developed by Memphis. In addition, this chapter lists the specific tasks performed in documenting the project. 
Chapter 2 Background/Project Construction

This chapter describes the construction process from start to finish. The implementation sequence and the time frame are discussed. A project sost comparison is presented to emphasize the magnitude of the component costs. Finally, problems or obstacles encountered during construction are described.

Chapter 3 Performance Evaluation

A performance evaluation is pressnted in chapter 3 . In this evaluation, the treatment plant parameters are discussed along with energy savings and environmental impact. An economic analysis of phase 1 is included in addition to a revised analysis of Phase 2 options.

\section{Chapter 4 Conclusions}

This section reviews the lessons learned during the project and outlines the remaining tasks for the project. 
CHAPTER TWO -- BACKGROUND/PROJECT CONSTRUCTION

REVIEN OF SIUDGE STABILIZATION

The stabilization phase of the wastewater treatment process is designed to render the waste inactive from further chemical reaction and destroy the disease-causing organisms in the waste stream. In addition to stabilizing the sludge, treatment substantially reduces the amount of suspended - ldge solids that must be landfilled after digestion is upleted. The two most popular methods of stabilization involve anaerobic and aerobic digestion.

Domestic wastewater consists of organic and inorganic wastes. Organic wastes are chemical substances from animals or plants which can be consumed by bacteria and other microorganisms. Inorganic wastes are chemical substances from minerals such as sand, salt, iron, calcium, etc. Inorganic wastes are not digestible by small organisms.

When domestic wastewater is discharged to a stream, oxygen-consuming (aerobic) bacteria feed on the organic waste while the inorganic wastes settle to the bottom of the stream. Aerobic bacteria extract dissolved oxygen from the water much like aquatic life breathes. The aerobic bacteria decompose the complex organic wastes into simple chemical compounds. As the bacteria feed on the waste, they 
reproduce rapidly causing a greater demand for oxygen from the water. Eventually, the dissolved oxygen level in the water is depleted and the aerobic bacteria die off.

When the dissolved oxygen is completely removed from the waste stream, anaerobic bacteria begin to further decompose the remaining organic compounds. Anaerobic bacteria extract oxygen from the chemical compounds, such as sulfate $\left(\mathrm{SO}_{4}\right)$, generated by the aerobic digestion process. When oxygen is removed from these sulfur compounds, hydrogen sulfide $\left(\mathrm{H}_{2} \mathrm{~S}\right)$, which has a "rotten egg" odor, is produced. Hydrogen sulfide is one of many unfavorable compounds formed by anaerobic bacteria. Methane $\left(\mathrm{CH}_{4}\right)$, on the other hand, is a byproduct of anaerobic digestion that can be used as an energy resource.

STILES WASTEWATER TREATMENT PLANT STABILIZATION PROCESS

After filtration, the biological portion of the treatment process utilizes numerous varieties of bacteria to remove organic pollutants from the wastewater. These microorganisms use the organic material as a food source. Initial biological decomposition occurs in two types of aeration tanks: contact tanks and stabilization tanks. Raw sewage is mixed with hungry microorganisms in the contact tanks. The organisus absorb their organic food source under ideal aerobic conditions. Four 5000 horsepower blowers force air through diffusers in the bottom of the aeration tanks to $\mathrm{mix}$ the waste and free the oxygen necessary to make the biological process work in a quick, efficient, and odor free manner.

The sewage/microorganism mixture remains in the contact tanks for less than two hours before it is sent to the 
secondary clarifiers. Here the microorganisms settle to the bottom while the clear sparkling effluent is treated and discharged into the Mississippi River.

The settled microorganisms are called sludge. Some of this sludge is reusea as a source of microorganisms for the treatment process and the excess is removed from the system. The sludge which is reused is pumped into the stabilization tanks where the microorganisms are kept under aerobic conditions for six hours in the absence of any additional food supply. By the end of the six hours the organisms have exhausted the food supply that they had stored internally and they are ready to digest more raw sewage in the contact tanks. This cycle is repeated over and over.

The plant generates over 300,000 dry pounds of excess sludge each day. The sludge undergoes aerobic digestion in a series of aeration tanks for a period of 12 days. This reduces the ability of the sludge to generate foul odors. Then the sludge is allowed to briefly flow through a gravity sludge thickener before it is pumped to two sludge storage lagoons. The average daily sludge flow to the lagoons is 3.0 million gallons.

The sludge is kept in these lagoons for approximately one year while it slowly gravity thickens so that its total volume is reduced by a factor of four. This naturally occurring anaerobic biological degradation produces a highly-stabilized sludge. The high degree of stabilization naturally results in the generation of significant volumes of methane-rich biogas. Recovery of this gas is a major focal point of the project. 
PROBLEM IDENTIFICATION

The Stiles Wastewater Treatment Plant (SWTP) began operation in 1977. Since it first opened its doors, the plant has continued to produce a high quality effluent and comply with all of its permit limits. In order to meet permit requirements, individual components of the treatment process must be periodically modified to improve efficiency and enhance performance. The sludge storage lagoons are very inexpensive to operate, but they do have problems.

The primary problem with the lagoons is the foul odor resulting from the anaerobic digestion of sludge. The odor adversely affects several communities in the vicinity of the plant, and as a result, the treatment plant operators receive complaints from residents on a routine basis. It is, therefore, difficult to emphasize the positive aspects of the facility when the public only perceives the negatives.

The effects of the odor problem are evident, not only in the complaints raised by local residents, but also in the lack of economic development in the area surrounding the SWTP. The high unemployment, significant population loss, pervasive poverty and deteriorated physical conditions of the area around the SWTP has resulted in its being designated as an "enterprise zone". Rehabilitation of the zone is being facilitated through local and state tax concessions, reduction in fees, innovative financing and the: encouragement of public/private partnerships aimed at revitalizing residential, commercial and industrial space. These efforts are being hindered by the offensive odors from the SWTP. By moving aggressively to resolve the odor problem 
at the SWTP, local government will further demonstrate its commitment to encouraging economic growth in the Memphis Enterprise zone (See Figure 1).

A mixed-use development on North Mud Island currently underway will also be affected by the activities and odors of the SWTP. Development plans include a marina, yacht club, retail stores, offices and approximately 1,000 residential units to be constructed on 132 acres of land which lies across the Wolf River from the SWTP. The single family homes planned at this "Harbor Town" development are expected to range in price from $\$ 150,000$ to $\$ 420,000$. New homeowners, who will have invested large sums of money for river views and the amenities of the Mud Island development, will likely demand that steps be taken to reduce the odors from the SWTP.

The SWTP had previously tried to address the odor problem. In fact, the SWTP was designed with aerobic digesters as an integral part of the treatment process to partially stabilize the sludge and reduce its odor potential prior to being placed in the lagoons. These aerobic digesters are still being used and help reduce the odors. The disadvantage of the aerobic digesters is the cost associated with their operation. About 25 peicent of the treatment plant's utility expenses are consumed by the aerobic digesters. The annual energy costs for the aerobic digesters in 1987 was about $\$ 872,000$. This expense is quite substantial since the digesters only reduce and do not eliminate the odors.

Another major problem with the lagoons is the biogas that is produced. These sludge lagoons are relatively large and release a significant amount of biogas into the atmosphere. Biogas has a heavy concentration of methane (over 60 percent) and carbon dioxide, which are 


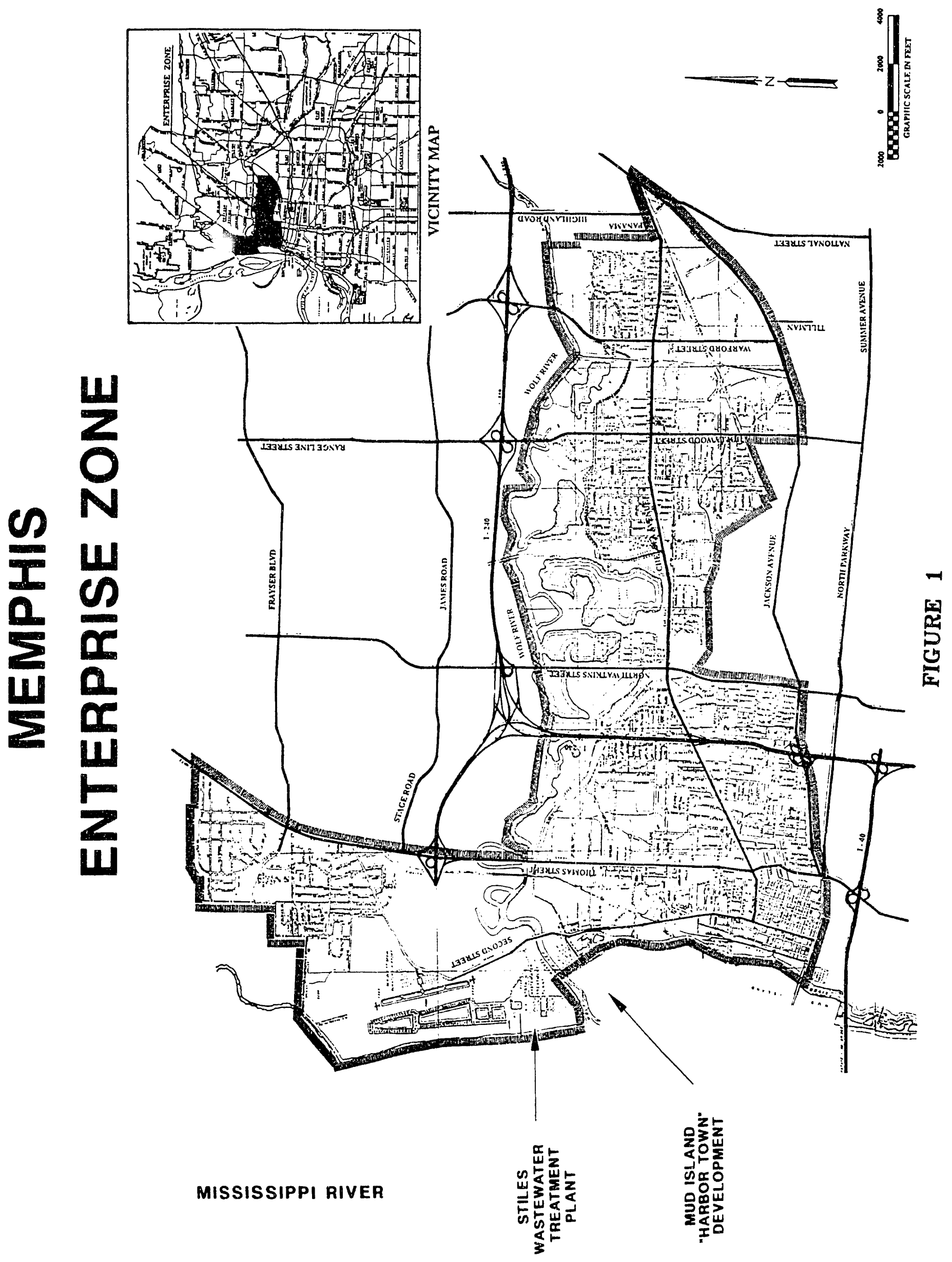


classified as "greenhouse gases." "Greenhouse gases" absorb infrared radiation (IR) reflected from the earth's surface and the sun. Methane is the greatest problem because it absorbs radiant energy twenty times more effectively than carbon dioxide. Scientific projections indicate that the buildup of IR energy by these "greenhouse gases" is leading to a net warming of the earth's atmosphere. This phenomerion has been called the "greenhouse effect." While wastewater treatment plants are not the only source of "greenhouse gases," they do disperse a large quantity of the gases from a concentrated area.

In addition to the environmental impact, biogas production also creates health and safety hazards. The primary components of biogas are methane, carbon dioxide, hydrogen sulfide, and methyl mercaptan. Methane and carbon dioxide are asphyxiants, and hydrogen sulfide (rotten egs smell) and methyl mercaptan (strong garlic smell) are both poisonous gases. Prolonged exposure to any of these gases is considered hazardous to human health. The symptoms of overexposure to these gases are headaches, dizziness, restlessness, sweating, eye irritation, convulsions, and nausea. Methane, hydrogen sulfide, and methyl mercaptan are also flammable gases which pose a safety hazard.

A final concern with the current treatment process is the needless waste of a perpetual energy source. The methane-rich biogas is presently being released into the atmosphere instead of being captured and utilized as fuel. The lagoons will produce methane as long as the treatment plant continues to operate. The combination of the odor and environmental problems with the opportunity for potentially using a previously wasted resource (biogas) as a new source of energy prompted the city of Memphis to solicit alternatives for biogas recovery from the lagoons. The city correctly determined that a single solution might well be 
able to eliminate long-standing problems with the SWTP while producing revenues or reducing operating costs for an essential service and improving the environment. From any political, economic or development perspective, the problems at the SWTP had the potential for being resolved to the benefit of the city and its residents.

PROPOSED SOLUTION

The City of Memphis contracted with ADI International to evaluate alternatives for containing and recovering biogas from the lagoons. ADI is a canadian-based consulting firm with experience in gas recovery from industrial process wastes. ADI examined several methods, from partial to complete covering of the lagoons, for capturing the biogas. The methods were judged not only on installation and operating costs but also on their effectiveness in controlling odors while eliminating the need for the aerobic digesters.

The most attractive method analyzed used a membrane to cover about 95 percent of the lagoon surface. This option recovers almost all of the escaping biogas and nearly eliminates the biogas odor while still allowing proper operation of the lagoons. The covers incorporate a biogas collection piping system which delivers the biogas to a remote blower building. The blowers pump the biogas to a pathological incinerator and a waste gas flare. The pathological incinerator will utilize the biogas as its fuel instead of natural gas. The surplus biogas is flared to eliminate migration and odor, thereby reducing the environmental impact on the local community. 


\section{Savings/Cost Analysis}

The primary savings associated with covering the lagoons results from the elimination of the aerobic digesters. As was mentioned earlier, these digesters consume a significant part (25 percent) of the overall utility consumption of the treatment plant. The annual power consumption of the blowers serving the aerobic digesters is approximately $52,100,000 \mathrm{kwh}$. Shutting down these blowers translates to a cost savings presently worth $\$ 872,000$ per year at $\$ 0.045$ per kwh.

Additional savings are obtained by utilizing the biogas as fuel for the municipal pathological incinerator. The revenue in displaced natural gas is estimated to be $\$ 45,000$ per year. The total annual savings from shutting down the digesters and fueling the incinerator with biogas is about $\$ 917,000$.

Covering the lagoons, however, would be a complex and expensive undertaking. The major system components include the lagoon covers, the biogas piping, a remote building housing the blower equipment, and a waste gas flare.

In addition to the initial installation cost, there will be an annual operation and maintenance (O\&M) cost associated with the biogas recovery system. The annual O\&M costs include parts, lubricants, and any incidentals required for the new biogas blowers. The annual o\&M costs for the new biogas equipment were estimated at $\$ 32,000$.

Removal of the aerobic digesters from the treatment process should reduce or eliminate some existing maintenance responsibilities. The aerobic digesters are served by two 5,000 horsepower blowers. Although these blowers have been relatively trouble-free since the opening of the SWTP 
in 1977, they do require preventative maintenance at an average annual O\&M cost of $\$ 10,000$. Therefore, the O\&M responsibilities will be shifted from the existing large blowers to the new biogas equipment. The net result in annual $0 \& M$ costs is an increase of $\$ 22,000$.

The total expense, including materials and installation, for the recovery system was estimated to be $\$ 3,656,000$. The annual savings generated from the reduced cost of operating the digester and incinerator, and offset by the increase in O\&M costs, is expected to be $\$ 895,000$. The simple payback for the project is 4.1 years with a return on investment of 0.24 .

\section{Additional Benefits}

In addition to the energy savings associated with this project, many additional benefits are expected. These benefits are difficult to evaluate from a monetary standpoint because they are somewhat intangible. Nonetheless, they have a great impact on the SWTP and the economic development of the surrounding community.

The greatest benefit of the lagoon covers is the virtual elimination of nuisance odors. The lagoon covers are designed to cover about 95 percent of the sludge lagoon surface, thereby, collecting nearly all of the biogas. The biogas is used as a fuel for the pathological incinerator and the excess is flared. The combustion process expels the odorous agents in the biogas. Eliminating the swTP odor should also eliminate any adverse effect the plant could have on the commercial/residential developments on Mud Island or in the Memphis Enterprise Zone. 
The combustion of the biogas also eliminates methane gas dispersion. Although carbon dioxide, which is a byproduct of combustion, is also a "greenhouse gas," methane contributes more to the "greenhouse effect" than carbon dioxide.

Another benefit expected from this project is that it will effectively increase plant capacity without incurring any construction expense. Currently, there are three sets of aeration tanks for processing the wastewater (contact tanks, stabilization tanks, and aerobic digester tanks). These tanks are identical in design but differ in operation according to their function. since the aerobic digester function will no longer be required when the lagoons are covered, the digester tanks may be converted to contact and stabilization tanks. This conversion will increase wastewater aeration capacity by almost 50 percent. This increase will allow postponement of future expansion of the SW'P to meet the increasing wastewater treatment demand of the community.

Due to their inexpensive operating costs, sludge lagoons are common to many wastewater treatment facilities. This is a unique project because it is the first municipal sludge lagoon to introduce covers into sewage treatment systems. This recovery system could be used by many other communities around the country. The experience that the city of Memphis gains through this project may be directly transferable to other communities with similar facilities.

CONSTRUCTION PROCEDURE

As discussed in Volume 1 , recovery and utilization of methane from the biological waste stream is not a new 
technology. However, the application of impermeable membrane covers to capture methane from waste lagoons is relatively new. Previously, covers have been used in a few small installations for industrial plants and the dairy industry.

The Memphis biogas recovery project has the distinction of being the only application in the world of a rembrane cover on a municipal wastewater sludge lagoon. It is also the largest lagoon cover system in the world. Therefore, special considerations were required in the design and construction of this unique project. Figure 2 provides an overview of the complete biogas collection system and indicates several design considerations discussed in the following sections.

\section{Site Preparation}

Startup activities (categorized under "mobilization" in the construction contract) involved the preparation of the site for crnstruction. Both ADI International (ADI), the design engineering firm, and M.D. Limbaugh Construction Company (MDL), the general contractor, established temporary offices on-site at the lagoons. Survey work was necessary to verify the site parameters used in the project design. Any discrepancies were factored into the construction phase. Also, construction equipment such as cranes and backhoes were brought on site to begin construction.

When construction was completed, the contractors vacated the premises and returned the site to its pre-construction conditions. "Demobilization" costs were also considered part of the site preparation. 


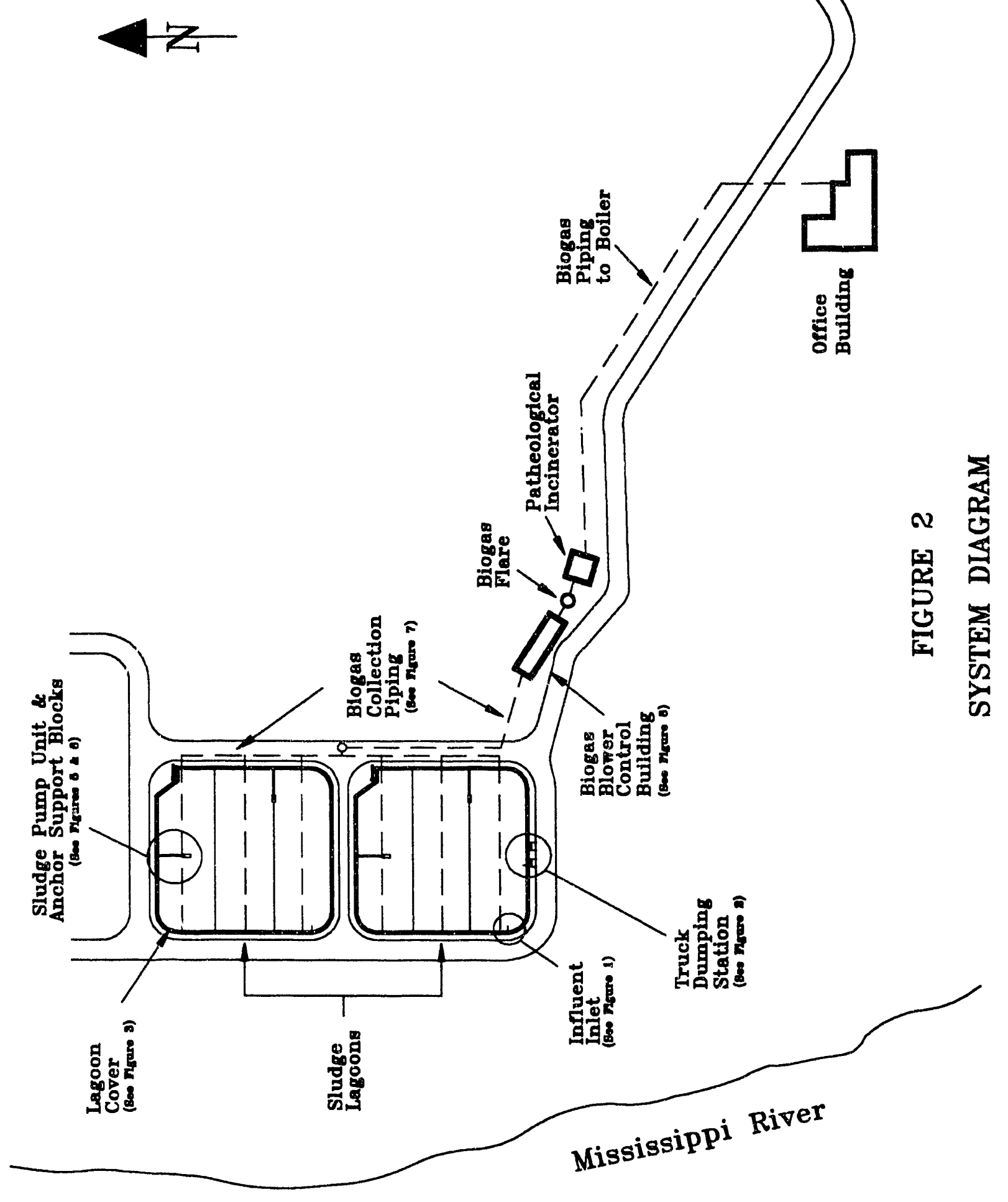




\section{Lagoon Covers}

Cover Fabrication. The cover material is typically purchased from the manufacturer pre-fabricated and ready for installation. Due to the size of this project, the city of Memphis decided to bid the cover material separately from the fabrication/installation in an effort to reduce the project cost. Therefore, when the cover material was delivered to the site, fabrication of the material into cover panels was required.

The contractor leased a facility to assemble the cover panels. The facility leased for assembly needed to be vacant and have a large, open room due to the size of the cover panels. The facility also needed to be relatively close to the construction site to avoid expensive transportation costs.

The cover design for the two lagoons required 180 panels measuring approximately 23 feet by 215 feet each. The cover material was shipped in rolls which were cut to proper dimensions and welded together. Each panel was fabricated to facilitate the weight lines and ridge floats for the rain water evacuation syster. The panel edges were detailed to contain pipes and tension cables. The corners were contoured to match the lagoon walls.

Structural Modifications. Before the covers were installed, several alterations to the lagoons were required to insure compatibility. Portions of the lagoon embankments had deteriorated over time from the variation of the sludge level and the corners had accumulated grit and sediment. The damaged areas were excavated and reworked to ensure proper fit and performance of the cover systems. 
The influent inlet consisted of steel line capped with a manual valve jutting from the wall of the lagoon. Influent was normally sprayed into the lagoon from the line several feet above the sludge level. To ensure that the cover system worked effectively, the influent inlet had to be extended down the wall under the sludge level and 30 feet into the lagoon (Figure 3 ).

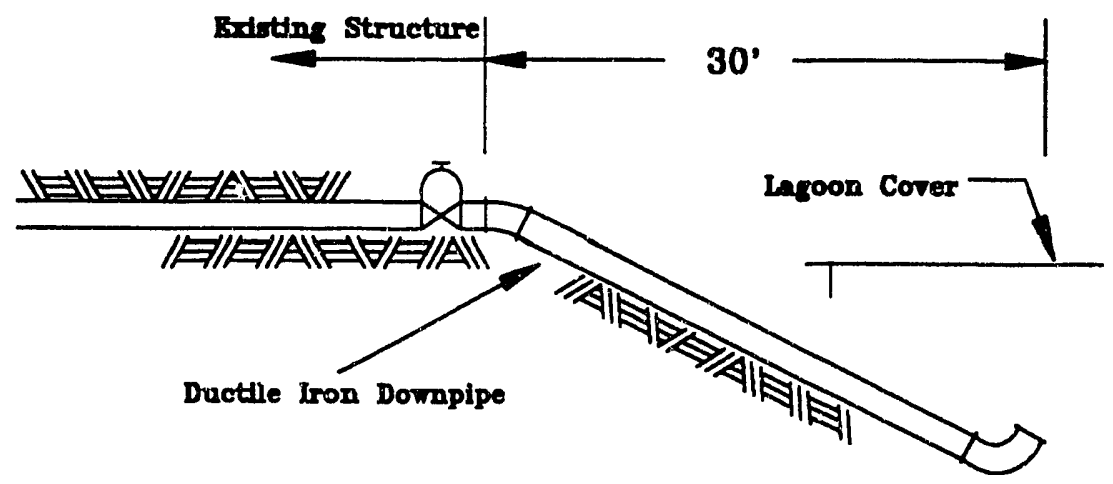

FIGURE 3

INFLUENT INLET EXTENSION

Sanitation trucks collect sewage daily from remote septic tanks and dump directly into the south lagoon. originally, the truck dumping station was modified so truck effluent could drain under the cover through a pipe extension. Figure 4 shows the modified truck dumping station. Due to large quantities of sediment, grit, and sand from the truck effluent accumulating under the cover, an alternative dump site was built near the front of the plant to process truck effluent through the treatment system. 


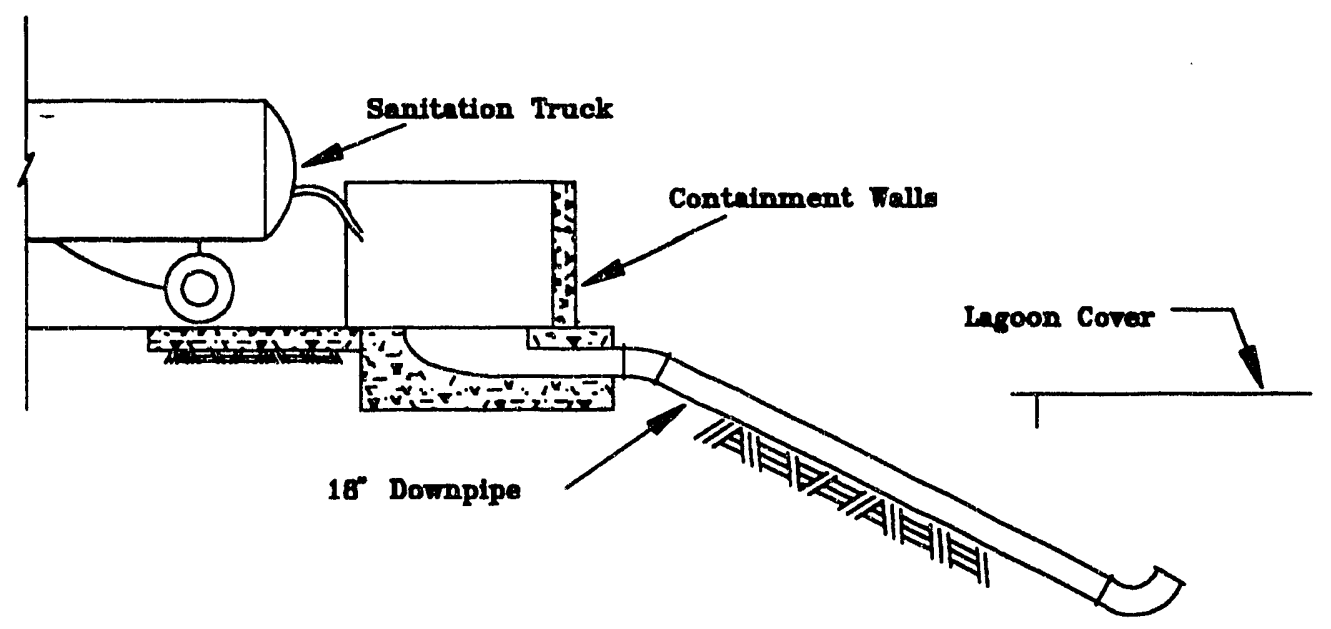

FIGURE 4 MODIFIED TRUCK DUMPING STATION

Ficld Instailation. The cover installation was the most elaborate task in the project because it involved several steps. Field installation included the cover assembly, cover launching, and cover securing processes. Installation was also complicated in that the operation of the lagoons could not be interrupted. The contractor had to maintain accessibility to the lagoons for plant personnel to perform normal. operation and routine maintenance.

The cover panels were fabricated at another site. When each panel was ready for assembly, it was rolled up and transported to the site by truck.

A launching area was prepared to assemble and launch the cover sections or "cells". The contractor covered the west wall of each lagoon with a ground sheet to provide a smooth area for unfolding the cover panels. The launching 
area also provided an area for the workers to attach the main biogas laterals and the cover insulation to the underside of the cover. The ground sheet prevented the insulation from being snagged or torn apart from the cover during the launching process.

The launch area was located in the central third of the west wall of each lagoon. On the launch area, thirty panels were welded together with sealant and overlapped stitching to make each cell. As the panels were joined, they were floated onto the lagoon by tow cables which stretched from the opposite side of the lagoon. When completed and fully launched, the first cell was shifted to the north third of the lagoon. The next celi was launched and shifted to the south third. The final cell was then launched into the middle of the lagoon. once the three cells were launched, they were seamed together to produce the complete cover (Figure 5).

While the cover sections were being launched, perimeter posts were installed in the lagoon walls. These posts are used to attach tension cables to hold the cover in its final position. Figure 6 shows a typical perimeter post installation.

With the covers in place, the remaining tasks included attaching cables from the perimeter pipes to anchor the edges of the cover and aligning weight lines to evacuate rain water from the cover. Should rainwater be allowed to remain on the cover, it forms pools between the biogas collection lateral pipes. These pools restrict the migration of the biogas under the cover to the collection laterals. The water also stresses the panel seams which may potentially tear. 

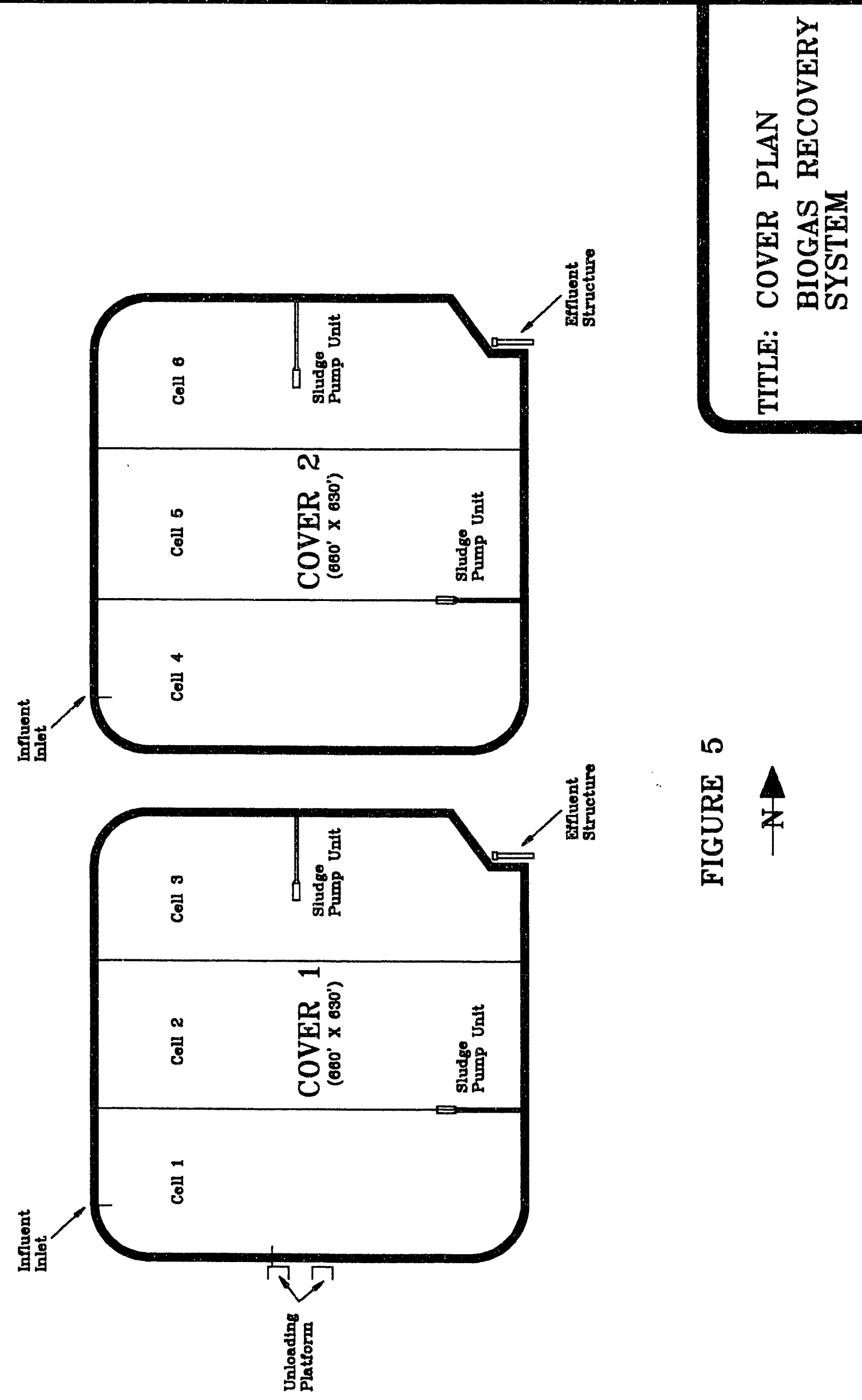

10

焉安 


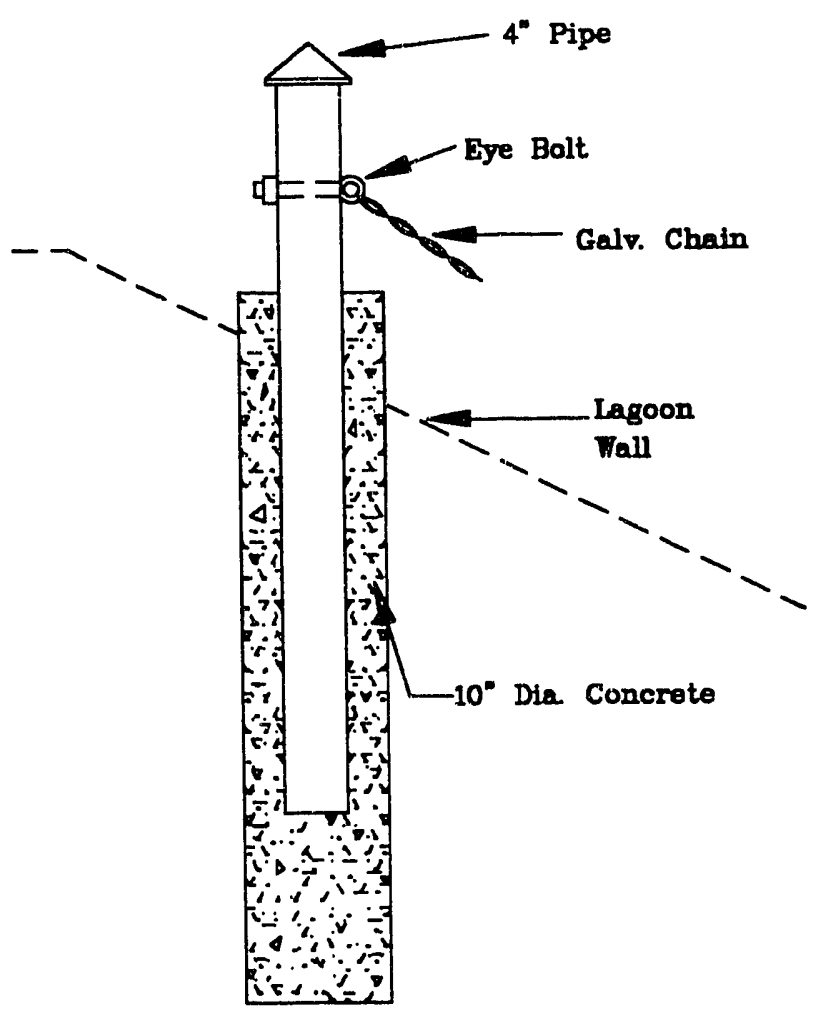

FIGURE 6 COVER ANCHOR

Sludge Barge Modifications. Two floating sludge barges are located in each lagoon. These barges carry pumps which pump matured sludge from the bottom of the lagoon to the dewatering facility. They were originally held in place by cables anchored to the lagoon wall. The barges are now mobile and used to service and replace the pump motors. 
The lagoon covers were designed with openings and access canals in the barge locations to allow continued movement of the sludge barges. The method for anchoring the barges was changed from previously used cables to large concrete anchoring blocks which were dropped to the bottom of the lagoon (see Figure 7). The openings have a support collar fox the sludge discharge piping and to permanently house the barges under normal operation. With the barge in place, the access canal is closed and fastened to insure the integrity of the cover. A typical opening and access canal is illustrated in Figure 8 .

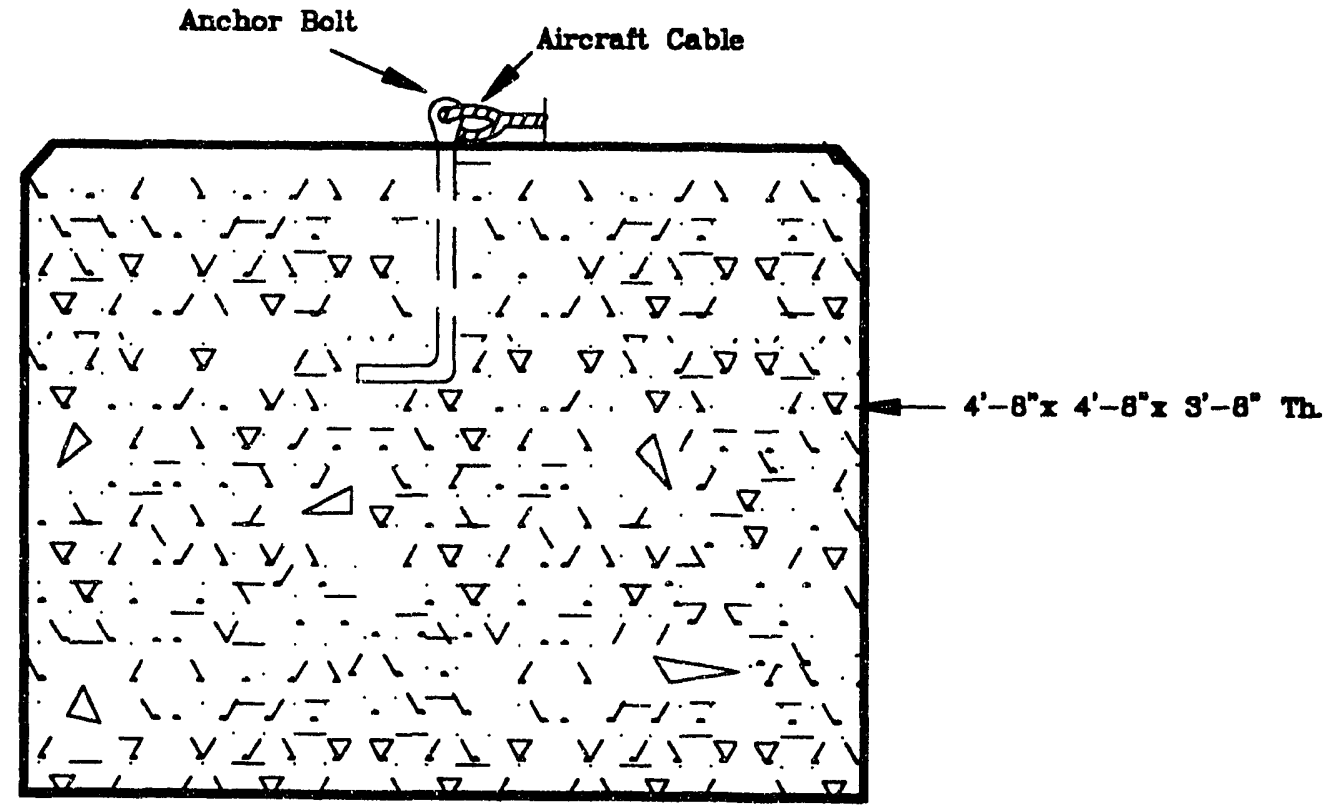

FIGURE 7

ANCHOR SUPPOR'T BLOCK

NOTE: 4 Required Per Raft 


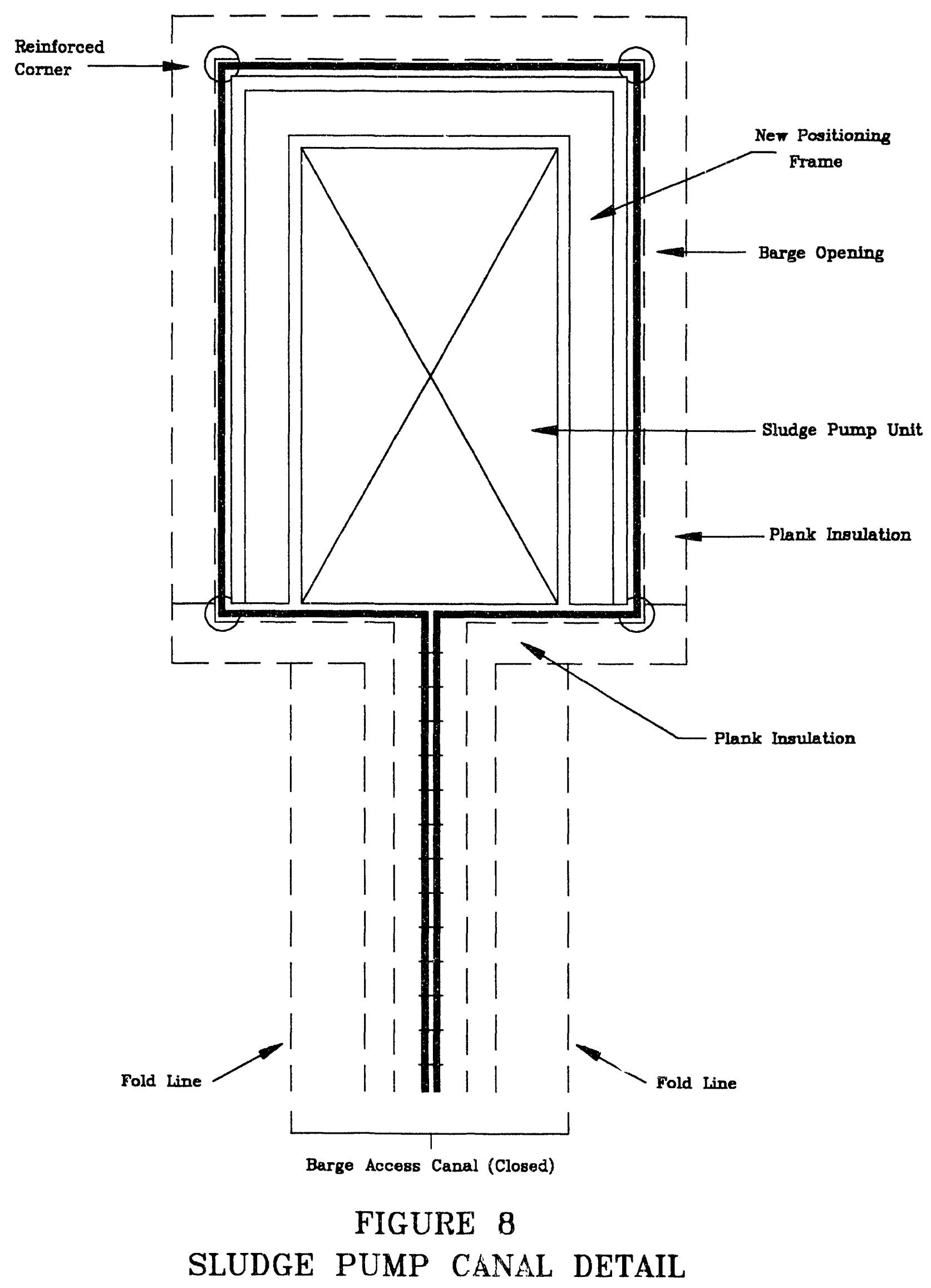




\section{Biogas Recovery system}

Piping. The piping system consists of: 1) belowground piping which delivers the biogas from the lagoons to the control building and 2) aboveground piping which runs through the control building to the incinerator and the biogas flare equipment. The belowground piping is polyvinyl chloride (pvc) while the aboveground piping is stainless steel.

Each lagoon cover has three biogas laterals. Each biogas lateral transitions into a 24 inch biogas header pipe buried in the east wall of each lagoon through a flexible connection assembly. This flexible connection assembly incorporates a vent pipe topped with a vacuum cap ventilator as shown in Figure 9. The ventilator is closed during normal operation and open when the biogas blowers are not operating to vent the biogas.

A 24 inch biogas header pipe runs the length of each lagoon. The headers join in a manhole between the lagoons and transition to a 12 inch pipe. This 12 inch pipe runs about 900 feet to a tee joint outside the control building. one leg of the tee drains moisture and sediment from the biogas line. The second leg of the tee begins the aboveground piping segment.

The 12 inch stainless steel pipe enters the control building and forms a header for the biogas blowers. A 5 inch takeoff feeds each blower. The blowers pump the biogas into an 8 inch header pipe which exits the control building and supplies the incinerator and biogas flare.

Control Building. A concrete block building was built between the lagoons and the incinerator to house the blowers which vacuum the biogas from under the covers. 


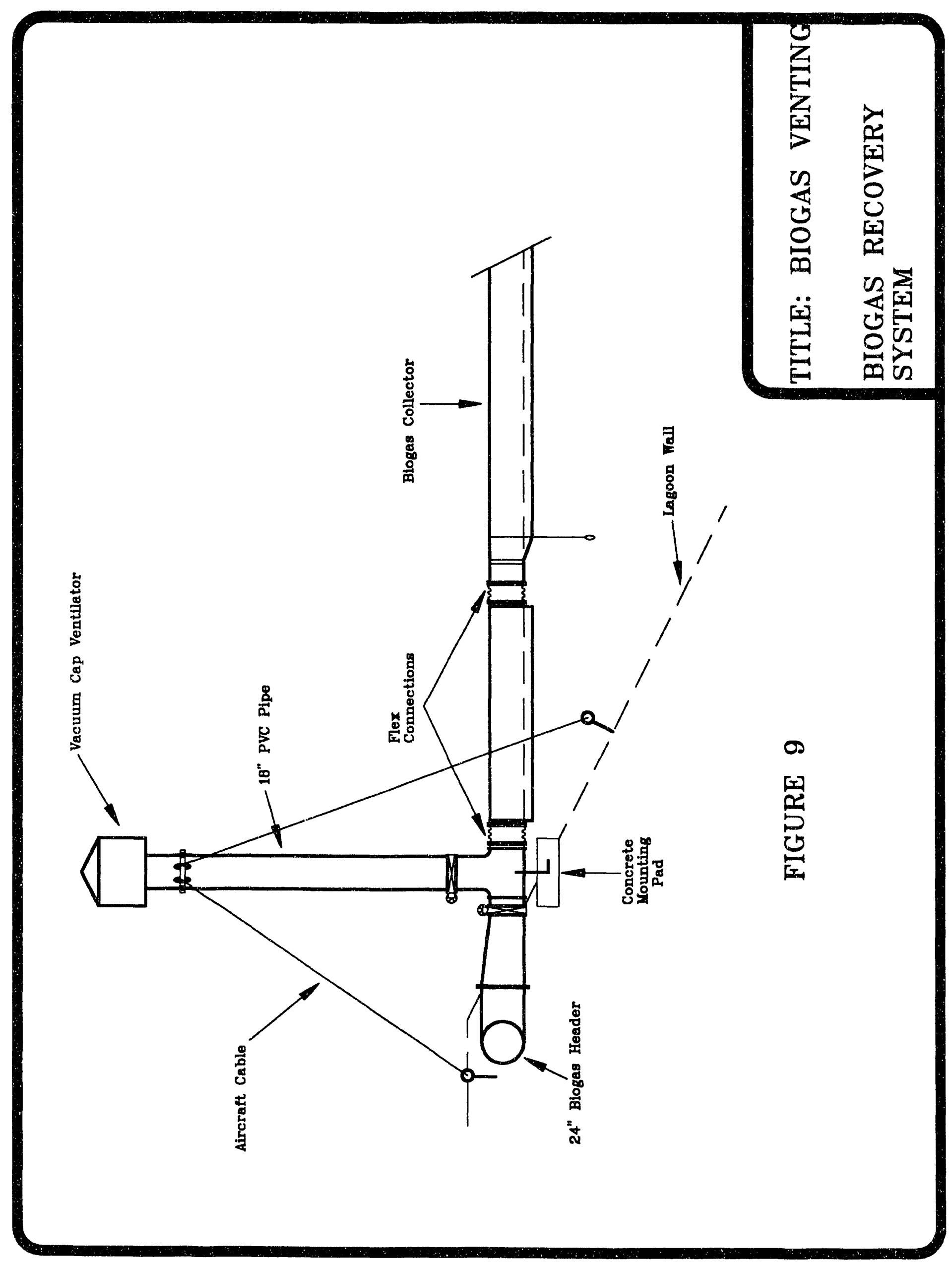


Five blowers were installed in the control building. Four of the blowers are twenty horsepower constant speed blowers. The fifth blower is a twenty five horsepower blower which is controlled by a variable frequency drive. A programmable logic controller (PLC) monitors the biogas pressure under the lagoon covers and operates the blowers to maintain a constant vacuum. The variable frequency drive allows the fifth blower to provide partial blower capacity when necessary. Figure 10 displays the floor plan of the control Building.

The PLC also monitors the biogas pressure downstream of the blowers to determine the quantity of biogas produced. A pressure signal is fed to the biogas flare control panel to modulate the flare operation.

CONSTRUCTION SCHEDULE

MDL submitted a construction schedule at the start of the project to indicate the planned progress. The schedule predicted the time frame of the entire project as well as the coordination of the different tasks. Figure 11 shows the planned construction schedule along with the actual events.

DELAYS/OBSTACLES

Actual construction took longer than planned. Several obstacles were encountered during the course of the project which caused uelays. Many of these obstacles affected more than one task, so the delays were compounded. 

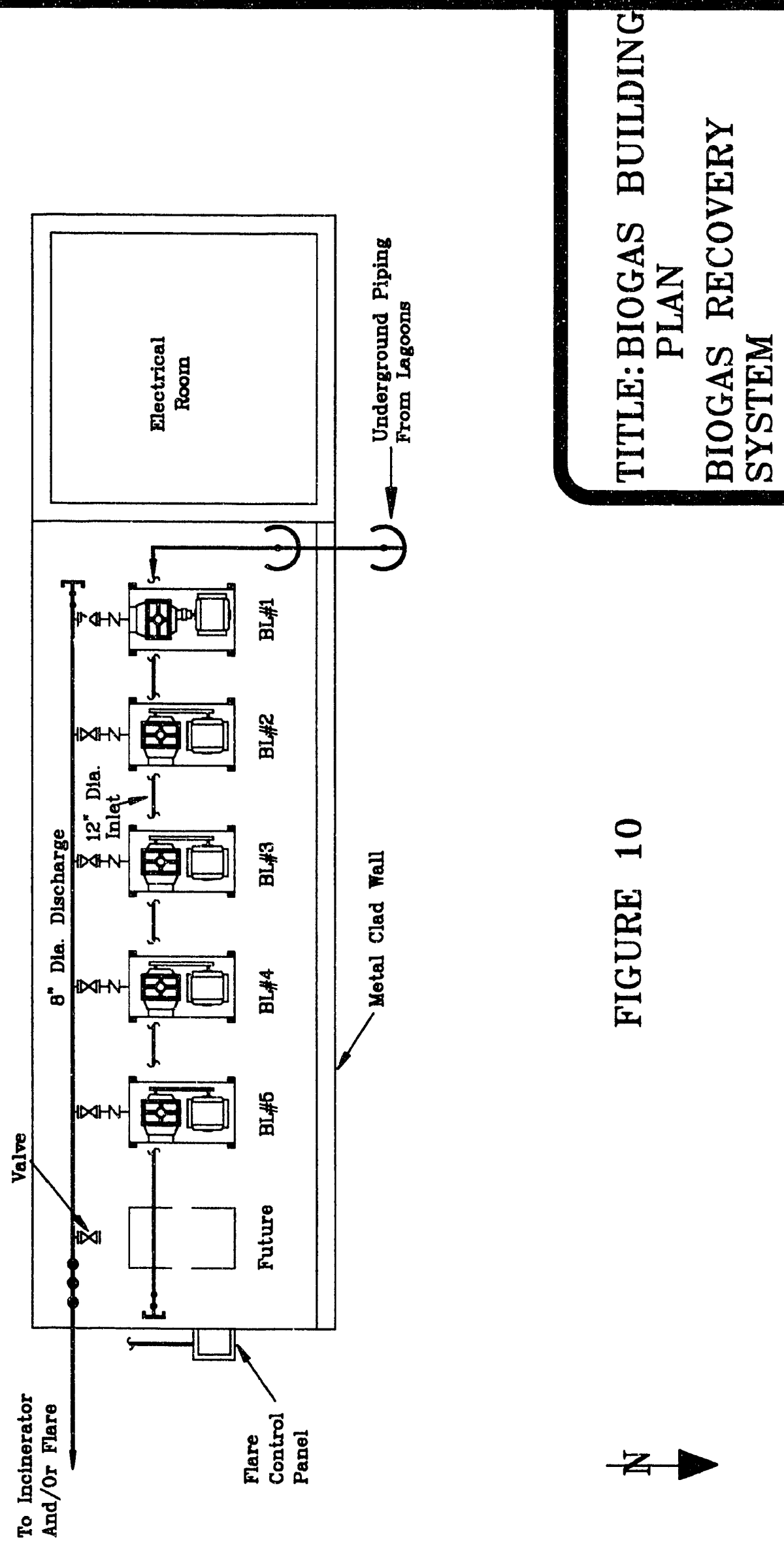


\section{FIGURE 11}

\section{CONSTRUCTION PROGRESS CHART}

\begin{tabular}{|c|c|c|c|c|c|c|c|c|c|c|c|}
\hline & & & & & 1890 & & & & & & \\
\hline & APR & MAY & JUN & JL & AUG & SEP & $\mathrm{OCT}$ & NOV & DEC & JAN & FEB \\
\hline Mobilization & & - & & & & & & & & & \\
\hline Shop Fabrication 2 & & & & & -- & $=$ & $=$ & & & & \\
\hline Shop Fabrication 1 & & $=-$ & $=-$ & $=$ & & & & & & & \\
\hline Structural Modification & & & & - & & -- & & & & & - \\
\hline Biogas Equipment & & & & & & & & & & & \\
\hline Underground Piping & & & & --- & & - & $=-$ & & & & \\
\hline Aboveground Piping & & & & & & & & - & & & \\
\hline Control Building & & & & & & & -- & & & & \\
\hline Field Installation 1 & & & & & -- & - & - & -- & - & - & \\
\hline Field Installation 2 & & & & & & & - & & & - & - \\
\hline Sludge Barge Modification & & & & & $=-$ & & -- & & & - & - \\
\hline Electrical & & & & & & & - & - & - & & - \\
\hline Controls & & & & & & & & - & & & \\
\hline Demobilization & & & & & & & & & & & \\
\hline
\end{tabular}

\begin{tabular}{|c|c|}
\hline \multicolumn{2}{|c|}{ LEGEND } \\
\hline Planned & \\
\hline Actual & --- \\
\hline
\end{tabular}


Cover Material. The material used for the cover membrane was a reinforced polymer-based fabric called XR-5 manufactured by seaman corporation. The material was delivered in large rolls and cut into panels per the design drawings. Some of the rolls of material were damaged and had to be reordered. This caused a slight delay in the fabrication process.

Scum Layer. Scum consists of certain oils, greases, and other materials which do not digest readily and form a top layer on the surface of the lagoons. This layer thickens over time and eventually traps other debris such as leaves, vegetation, and trash. When strong winds occur, the scum tends to foam and become even thicker.

Scum layers: (a) occupy volume needed for digestion, (b) interfere with effective circulation, mixing, and temperature control, (c) affect the quality of the supernatant withdrawn from the lagoon, and (d) interfere with gas separation and collection.

The two lagoons included in this project had developed substantial scum layers. It was obvious the scum layer would cause delays and frustration during cover installation and could be potentially damaging to the cover. Therefore, the contractor had to devise a method of removing or containing the scum layer.

The contractor chose to stretch a boom across the lagoon and skim the scum layer to the lagoon wall. A dragline was used to bail the scum out and load it into trucks. This method was effective; however, several passes were necessary to keep the lagoon surfaces clear during installation. The scum layer problem delayed the field installation by almost two months. 
Stainless steel piping. Stainless steel piping was specified for the aboveground piping in the control building and the flare system due to the corrosive nature of biogas. The supplier had difficulty locating the type and quantity of piping required for the job. The supplier ultimately delivered the piping more than a month after the original due date. This naturally delayed the installation of the aboveground piping, and it also delayed the construction of the control building and the installation of the biogas equipment and the associated controls.

project coordination. This was a large scale project constructed by one general contractor and two primary subcontractors. Although the project seemed to run smoothly, problems with coordination of the tasks between the subcontractors contributed to some of the delays. Schedule delays and changes eventually affected the availability of certain contractor crews to perform their specified tasks when required.

PROJECT COST ANALYSIS

When evaluating the success of any energy conservation project, it is important to compare the actual construction cost to the preliminary cost estimate used to justify funding. Information gained from the cost analyses can then be factored into future projects to improve the accuracy of preliminary estimates. This section examines the cost comparison of major components of the biogas recovery project. Table 1 presents an itemized list of the major tasks involved in the project as defined by the preliminary engineering study and the actual construction contract. 


\section{TABLE 1}

\section{Project Cost Comparison}

1. Engineer ing

2. Site Preparation

3. Impermeable Niembrane

4. Shop Fabrication

5. Insulation

6. Cover Weights

7. Perimeter Ties

\& Miscellaneous

8. Biogas Collector Laterals

9. Biogas Recovery System

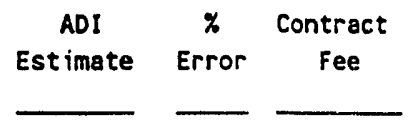

$302,200 \quad 0 \quad 302,200$

$170,000 \quad-2 \quad 166,000 \quad\left\{\begin{array}{l}150,000 \\ 16,000\end{array}\right.$

$\left.\begin{array}{l}918,000 \\ 652,500\end{array}\right\} 1,570,500+6 \quad 1,667,703 \quad\left\{\begin{array}{c}527,703 \\ 1,140,000\end{array}\right.$

$\left.\begin{array}{l}364,500 \\ 124,200 \\ 572,400 \\ 196,200\end{array}\right\} 1,257,300+13 \quad 1,428,000$

$$
\left\{\begin{array}{l}
8 \\
1
\end{array}\right.
$$

890,000

43.001

120,000

75,000

300,000

4. Impermeable Membrane **

5. Shop Fabrication

6. Field In tallation

7. Structural Modifirations

8. Sludge Barge Modifications

9. Aboveground Piping

10. Belowground Piping

30,000 11. Control Building

250,000 12. Biogas Equipment

20,000 13. Controls

54,000 14. Electrical

Totals

* Separate Contract for engineering desiç. 15\% applies to Phase 2 design.

* Separate contract for cover material only. 
Engineering. The fee for engineering design of the project did not change from the preliminary estimate since the City of Memphis hired the engineering firm who conducted the study. It would have been unwise to hire another firm considering the specialized nature of the project and the time invested performing the preliminary work.

Site Preparation. The contract fee was 2 percent less for site preparation than the original estimate.

Impermeable Membrane/Shop Fabrication. The design specification for the membrane material allowed use of two different cover materials: high density polyethylene (HDPE) and a reinforced polymer based fabric (XR-5). The city chose to bid the cover material separately from cover construction. It was determined that a competitive bid situation would be in the best interest of the city. In fact, when the cover material was selected, the bid price was almost 43 pexcent less than the preliminary estimate.

The shop fabrication process, however, yielded opposite results. The shop labrication cost was 75 percent higher than the estiuate. Shop fabrication is the assembly of the 180 panels required. Each panel consists of 5 strips of the material weided and cut to proper dimensions. In smaller industrial applications, the cover is purchased pre-fabricated directly from the manufacturer ready for installation. However, shop fabrication was a separate bid item for this project. Therefore, the main factor contributing to the price discrepancy was the requirement for an off-site facility for cover fabrication. The contractor had to lease a facility large enough to assemble the panels. 
As part of the off-site fabrication process, the contractor had to devise a mobile fabrication system. When purchased pre-fabricated, the manufacturer cuts and assembles the cover panels at the plant with stationary machinery ill-equipped for mobile operations. Since this application was unique, the contractor had to procure mobile equipment to assemble the cover panels and deliver them to the site.

Finally, the assembly of the cover required a contractor with specific expertise. No local contractor had experience with this type of installation, so an out-of-town contractor was hired for the fabrication and installation process. Due to the time required for the project, the expense of supporting an out-of-town labor force added to the cost of construction.

While the contract costs for the membrane and shop fabrication are drastically different from the original estimate, the cost difference is only 6 percent when the two items are viewed collectively.

Insulation/Cover Weights/Perimeter Ties $\&$ Miscellaneous/Biogas Collector Laterals. The construction contract referred to these items as field Installation, structural Modifications, sludge Barge Modifications, Aboveground piping, and Belowground piping. The contract cost for these items was 13 percent more than the preliminary estimate. This section accounts for over one third of the total project cost and the bulk of the on-site work.

The supply and installation of the biogas system covered the control building, biogas equipment, controls, and electrical work. The construction of the incinerator was under a completely separate contract. All of these 
items have stable prices and limited labor costs making them easy to estimate. costs differed by only $0.5 \%$.

As with all construction projects, changes and extras occured due to unforeseen site conditions and other reasons. on this project cost overruns were almost offset by savings and did not significantly affect the total cost.

Summary. The total project cost for design and construction was only 7 percent higher than the preliminary engineering estimate. This is remarkable considering the magnitude and specialized nature of this project. In most private sector applications, the customer purchases a "turn-key" installation for a fixed fee. By requiring separate contracts for engineering design, cover material, and project construction, the City of Memphis naturally exposed itself to the potential for a price increase.

Perhaps the most significanc factor causing the construction cost increase was inflation. The preliminary engineering study was completed in March 1987. The construction contract was signed in January 1990. Between the time the engineering study was completed and the construction contract was signed the consumer price index increased by 15 percent. Considering the inflation rate, a 7 percent variance from the estimated project cost is very reasonable. 
CHAPTER THREE -- PERFORYANCE EVALDATION

PHASE 1 ANALYSIS - BIOGAS RECOVERY

Purification of wastewater before its discharge to receiving waters has become a sophisticated science. The treatment process is designed to respond to the many characteristics of the wastewater. Prysical characteristics include water temperature, odor, color, and flow. The chemical properties of wastewater are divided into organic and inorganic matter. Chemical concentrations such as solids content, biochemical oxygen demand, ph levels, and nitrogen content affect the treatment strategy. Environmental parameters including rainfall, flood stage, and ambient temperature vary the reaction rate of the process. Each of these factors contributes to the costs of operating a wastewater treatment plant.

In evaluating the success of the lagoon cover system, these wastewater characteristics were examined to find the most significant factor affecting energy consumption. Biochemical oxygen demand or BOD displayed the best correlation to energy use. BOD is the rate at which microorganisms use oxygen in wastewater decomposition. In decomposition, organic matter serves as food for bacteria and energy results in the form of heat from its oxidation. BOD is measured as the concentration or weight of organic material in wastewater which can be biodegraded using free oxygen. Samples of wastewater are tested periodically to 
determine the concentration of organic material. This concentration is multiplied by the flow rate of wastewater through the plant (gallons per day) and the weight of water (8.34 pounds per gallon) to calculate the daily BOD loading (pounds per day). Graph 1 shows the linear relationship between monthly BOD loading and kilowatt-hour (kwh) consumption.

GRAPH 1

\section{Stiles Treatment Plant \\ KWH vs. BOD}

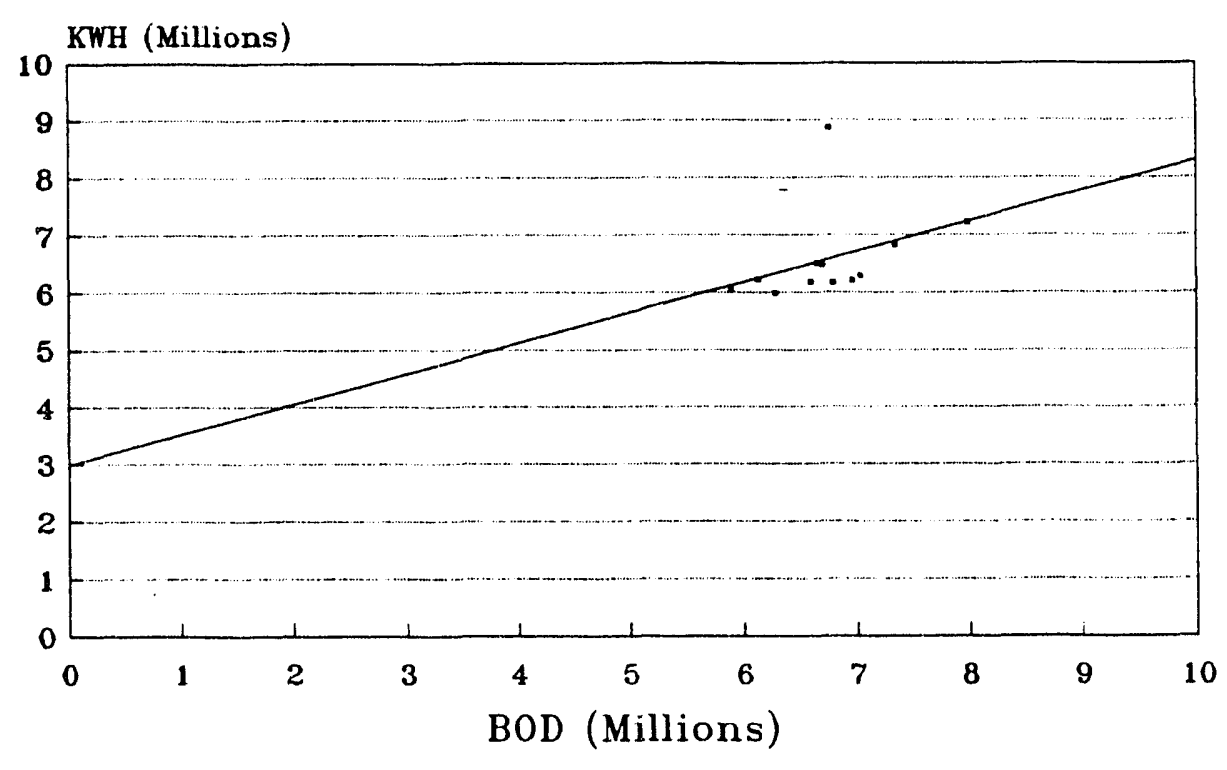

Treatment Plant Data

One year of historic plant data was needed to establish the relationship between BOD loading and energy consumption. Repair of a large sewer main rupture in 1989 and the construction of the lagoon covers in 1990 caused several months of irregular operation of the treatment process. 
Consequently, 1988 was selected as the base year because it closely represented normal operation of the treatment plant. Table 2 lists the monthly electricity consumption, the monthly electricity cost, and the monthly BOD data for 1988 . Table 3 gives similar data for the first six months of 1991 .

\section{Table 2}

\section{SWTP Data}

\begin{tabular}{|c|c|c|c|}
\hline Month & $\begin{array}{l}\text { Electricity } \\
\text { Consumption } \\
\left(10^{6} \mathrm{kwh}\right) \\
\end{array}$ & $\begin{array}{l}\text { Electricity } \\
\text { cost }\end{array}$ & $\begin{array}{c}\text { BOD } \\
\text { (1bs. per } \\
\text { month) } \\
\end{array}$ \\
\hline January & 7.2192 & $\$ 326,325$ & $7,991,986$ \\
\hline February & 6.1824 & 297,098 & $6,591,564$ \\
\hline March & 6.2880 & 287,317 & $7,034,613$ \\
\hline April & 6.2016 & 286,196 & $6,957,540$ \\
\hline May & 6.8160 & 300,980 & $7,350,565$ \\
\hline June & 6.2112 & 282,922 & $6,127,890$ \\
\hline July & 6.4800 & 298,827 & $6,702,913$ \\
\hline August & 8.8704 & 363,820 & $6,759,271$ \\
\hline September & 6.0576 & 279,972 & $5,890,620$ \\
\hline October & 6.4992 & 294,570 & $6,652,228$ \\
\hline November & 5.9904 & 279,113 & $6,279,510$ \\
\hline December & 6.1632 & 294,912 & $6,780,971$ \\
\hline Totals & 78.9792 & $\$ 3,592,052$ & $81,119,671$ \\
\hline Average & 6.5816 & 299,338 & $6,759,973$ \\
\hline
\end{tabular}


Table 3

$$
\begin{aligned}
& 1991 \text { SWTP Data } \\
& \text { (Year-to-date) }
\end{aligned}
$$

\begin{tabular}{|c|c|c|c|}
\hline Month & $\begin{array}{l}\text { Electricity } \\
\text { Consumption } \\
\left(10^{6} \mathrm{kwh}\right)\end{array}$ & $\begin{array}{l}\text { Electricity } \\
\text { cost } \\
\end{array}$ & $\begin{array}{c}\text { BOD } \\
\text { (1bs. per } \\
\text { month) }\end{array}$ \\
\hline January & 6.0768 & $\$ 286,323$ & $7,023,639$ \\
\hline February & 5.6256 & 266,822 & $6,495,160$ \\
\hline March & 5.2654 & 273,058 & $7,306,824$ \\
\hline April & 5.5363 & 210,822 & $6,810,000$ \\
\hline May & 6.0762 & 232,995 & $7,750,000$ \\
\hline June & 5.6034 & 216,401 & $7,442,520$ \\
\hline
\end{tabular}

The construction of the lagoon covers and the biogas recovery system was completed in February 1991. The biogas system controls were damaged in a thunderstorm in March 1991 postponing the switchover to the new system operation. Tables 2 and 3 show a dramatic reduction in monthly electricity costs for April, May and June 1991. Although these were the first three months the biogas recovery system was fully operational, the full cost savings cannot be attributed to the lagoon cover system. Memphis Public Works has implemented other cost reduction programs, including a restructuring of the utility rate schedule, which just happened to coincide with the cover project completion.

\section{Utility Rate Schedule Modification}

Growth trends predict that electricity demand is approacl.ing the peak generating capacity of existing plants in the Tennessee Valley Authority (TVA) system. TVA has responded by developing several incentive programs to better manage 
their connected electrical load. These incentive programs rewind customers who: 1) add substantial electrical loads by expanding their plants and workforce, 2) will reschedule their production times to off-peak periods, or 3 ) are able to endure temporary interruptions of utility service.

One of these incertive programs is a special electric rate schedule called economy surplus power (ESP). The ESP rate is designed for customers with electrical demands over 2,500 kilowatts $(\mathrm{KW})$. Under the ESP rate, the customer is subject to temporary interruptions of electrical service on short notice. To date, the risk has been relatively low, with only one interruption in the Memphis area since the program began in 1987.

The customer benefits from both reduced electricity consumption (kwh) charges and demand (kw) charges. The ESP consumption charge is the TVA production cost plus approximately 20 percent. This charge changes throughout the billing period with TVA's production cost as it varies with system loading. The savings thus far have averaged almost $\$ 0.006$ per kilowatt hour.

The customer also receives a reduction in demand charges by only paying for the portion of electrical demand designated as non-interruptible. When the original ESP agreement is signed, the customer designates a portion of his electrical demand (up to 50 percent of peak demand) which may not be interrupted. All electrical demand above this contract amount is considered interruptible and is free of charge. The contract also establishes penalties for excessive consumption and demand.

Memphis Public Works switched the wastewater treatment plants to the ESP rate effective April 1991. 


\section{Energy Savings Summary}

Although the utility rate schedule change complicates the cost savings analysis, it is still possible to extract individual savings for specific measures. Even though both savings measures reduce the overall cost of the treatment process, they do it by different methods. The sludge lagoon biogas recovery project focuses on reducing the electricity consumption required for wastewater treatment. The ESP utility rate schedule change merely offers electricity at a lower unit cost provided that the user can withstand an interruptible power supply.

By manipulating the treatment plant data supplied in Tables 2 and 3 , cost and consumption rates per unit of production are derived. Table 4 summarizes these numbers and shows the impact of both cost reduction measures. 
Table 4

1988 Data

$\begin{array}{lccc}\text { Month } & \text { Kwh/BOD } & \frac{\$ / k w h}{1} & \frac{\$ / B O D}{1} \\ \text { January } & 0.90 & 0.044 & 0.041 \\ \text { February } & 0.94 & 0.046 & 0.045 \\ \text { March } & 0.89 & 0.044 & 0.041 \\ \text { April } & 0.89 & 0.044 & 0.041 \\ \text { May } & 0.93 & 0.042 & 0.041 \\ \text { June } & 1.01 & 0.044 & 0.046 \\ \text { July } & 0.97 & 0.044 & 0.045 \\ \text { August } & 1.31 & 0.040 & 0.054 \\ \text { September } & 1.03 & 0.044 & 0.048 \\ \text { October } & 0.98 & 0.044 & 0.044 \\ \text { November } & 0.95 & 0.045 & 0.044 \\ \text { December } & 0.91 & 0.046 & 0.043 \\ & & & 0.044\end{array}$

1991 Data

$\begin{array}{lrcc}\text { January } & 0.87 & 0.045 & 0.041 \\ \text { February } & 0.87 & 0.047 & 0.041 \\ \text { March } & 0.72 & 0.048 & 0.037 \\ \text { *April } & 0.81 & 0.037 & 0.031 \\ \text { *May } & 0.78 & 0.039 & 0.030 \\ \text { *June } & 0.75 & 0.039 & 0.029 \\ & & & \\ \text { Avg. (Apr-June 91) } & 0.78 & 0.038 & 0.030 \\ \text { Avg. (Apr-June 88) } & 0.94 & 0.043 & 0.043 \\ \text { Percent Reduction } & 17 \% & 12 \% & 30 \% \\ \text { * First months of near normal operation of biogas } \\ \text { recovery system. }\end{array}$


By eliminating the aerobic digesters from the treatment process, the SWTP has reduced the electricity consumption required to process each unit of BOD loading. The energy consumption rate per unit of $B O D$ loading is indicated in Table 4 by the ratio of kwh to BOD. The average consumption rate from April through June 1988 of $0.94 \mathrm{kwh} / \mathrm{BOD}$ has been reduced to the 1991 average consumption rate of 0.78 kwh/BOD. This is a 17 percent reduction in electricity consumption. Based on the total electricity costs in 1988 of $\$ 3,592,052$, the projected annual savings resulting from eliminating the aerobic digesters is $\$ 611,000$ per year.

Projected Annual Savings $=\$ 3,592,052 \times 0.17=\$ 611,000 / \mathrm{Yr}$.

The conversion of the SWTP electric service to the ESP utility rate schedule has reduced the cost per unit of electricity purchased $(\$ / \mathrm{kwh})$. As Table 4 shows, the unit cost of electricity was reduced from $\$ 0.043 / \mathrm{kwh}$ in 1988 to $\$ 0.038 / \mathrm{kwh}$ in 1991 yielding a 12 percent reduction. Bised on the 1988 electricity costs, switching utility rate schedules saved the SWTP approximately $\$ 431,000$ per year.

Projected Annual Savings $=\$ 3,592,052 \times 0.12=\$ 431,000 / \mathrm{yr}$.

The combined effect of both measures is evident in the overall cost to process each pound of BOD (\$/BOD). The 1988 cost of $\$ 0.043 / \mathrm{BOD}$ has been reduced to $\$ 0.030 / \mathrm{BOD}$ for 1991 , which is a total cost reduction of approximately $\$ 1,042,000$ per year. 
Additional Energy Saving opportunities

In 1990, the city completed construction of a new natural gas-fired patheological incinerator which is operated by the Sanitation bivion. The incinerator was located next to the sludge lagouns so that the collected biogas could be used as fuel. The new incinerator requires a modified burner to be able to burn the biogas. Several boiler manufacturers were contacted during the construction phase of the lagoon covers project, but were reluctant to sell only the burner attachment. Therefore, the incinerator has not yet been converted to biogas.

The city has now contracted with a local engineering firm to design the burner modification so the incinerator may burn biogas and the engineering firm has already located a boiler manufacturer interested in the project. Public Works expects the boiler conversion to be completed by the winter or spring of 1992. The ADI feasibility study predicted an annual savings of $\$ 45,000$ to the City in avoided natural gas costs due to the biogas conversion.

In addition to the patheological incinerator, the city is going to use the biogas to heat the administrative and operations buildings at the treatment plant. These buildings were originally built with electric heat incorporated into the air conditioning system. Memphis Public Works contracted a local mechanical engineering firm to design a space heating system that will be fueled on the biogas. The new system includes a biogas-fueled boiler which supplies hot water to replacement heating coils in the air handling units. The project will reduce the heating cost of the treatment plant by $\$ 36,000$ per year. The project cost is $\$ 210,000$. Public Works is proceeding with construction which is scheduled for completion in December 1991. 
Environmental Impact

Scientific research has indicated that carbon dioxide and methane are the principle contributors to the global warming phenomenon called the "greenhouse effect". These gases along with the other greenhouse gases comprise less than one percent of the earth's atmosphere. However, any change in their concentrations alters the capacity of the atmosphrse to retain thermal radiation. Atmospheric samples indicate that the concentration of carbon dioxide is several hundred times that of methane. The properties of methane, on the other hand, make it twenty times more effective than carbon dioxide in absorbing radiant heat. Although increasing atmospheric quantities of either carbon dioxide or methane may be hazardous, current theories suggest that a significant increase in methane is more detrimental.

Sludge produced at the SWTP has the potential to generate about 580,000,000 cubic feet of biogas per year. The biogas composition is 66 percent methane, 28.3 percent carbon dioxide, and 5.7 percent other impurities (water, hydrogen, hydrogen sulfide, and nitrogen). The new lagoon covers capture about 96 percent of the sludge biogas. This biogas is burned through a gas flare thereby converting the methane to carbon dioxide and water. Therefore, although the greenhouse gases are not eliminated, the amount of methane added to the atmosphere is significantly reduced.

The lagoon cover system also dramatically reduces the objectionable odors emanating from the SWTP. This was clearly evident following a severe thunderstorm in March 1991. Lightning damaged some of the control sensors causing a shutdown of the biogas recovery system. The emergency venting system functioned as it was designed and disbursed 
the captured biogas to the atmosphere. As a result, the treatment plant received numerous complaint calls from the surrounding community regarding the offensive odor.

\section{Economic Development Benefits}

The recovery of biogas from the sludge storage lagoons should result in several economic development benefits for the city of Memphis. First, the reduction of offensive odors from the SWTP should assist the economic growth of the surrounding community which heretofore has been underdeveloped. In addition, the recovery of biogas from the sludge storage lagoons will benefit the Memphis industrial base through increased treatment capacity and stable sewer fees.

New and expanding companies considering Memphis as a possible business location have always been impressed by the capability of the city's sewage treatment plants. Companies whose production processes require sewage treatment find Memphis a very attractive location for business because the need to build on-site treatment plants is virtually eliminated.

Converiing the abandoned aerobic digester tanks to contact and aeration tanks will increase the treatment plant capacity by 50 percent without any new construction. This additional increase in capacity will aid the economic development efforts that are underway to encourage large industrial companies and users to locate in the Memphis area.

The comined impact from shutting down the aerobic digesters and converting the treatment plant's electric rate schedule to the Economy surplus Power (ESP) rate will reduce 
the annual utility costs of the treatment plant by approximately $\$ 1,042,000$. This represents a 32 percent reduction in the costs of operating the plant. These funds will be funnelled back into the operating fund for the treatment plant and may be tapped for the development of new processes or expansion. Furthermore, the recapture of these funds will allow the city to provide a higher level of service at the current level of fees. Under this fee structure, Memphis will probably continue to have the lowest sewer rate in the country for at least the next five years. This will make the cost of operating industrial plants in Memphis very competitive.

The Memphis sewage treatment facilities are expected to become a more important factor in recruiting industries. Memphis will be most attractive to companies, especially large industrial processors, who focus on locating in areas with facilities that positively impact their production costs. Using the sludge storage lagoons for biogas recovery will significantly increase Memphis' ability to attract and retain new, expanding and relocating industries.

\section{Problems During system startup}

Project construction was originally scheduled to be completed by the summer of 1990. Delays in the bid process, contract negotiation, and construction postponed project completion to February 1991. These delays also reduced the time frame allotted for monitoring new plant operation. As a result, savings figures presented do not cover a full six month period as was originally anticipated.

Once on-line, several circumstances prohibited the treatment plant from immediately achieving the cost savings predicted in the ADI feasibility study. 
1) The City of Memphis suffered record amounts of rainfall during January and February 1991. This excessive rainfall increased the influent flow rates substantially which forced plant personnel to alter normal operating procedures.

2) Lightning disabled the aeration optimization (AEROPT) computer which controls mechanical ventilation for the contact and aeration tanks. The system was down for 26 days during April 1991. During this period the system was controlled manually by plant personnel familiar with optimum control settings; however, maximum savings were not obtained since typical plant operation was disrupted.

3) When the biogas recovery system was activated, the aerobic digester tanks could not instantly be shut down. The aerobic digesters were drained gradually to maintain the biochemical stability of the treatment system. As the tanks were drained, the aeration blowers were gradually slowed to keep the proper oxygen ratio in the wastewater. The draining process took a few weeks to reach the desired conditions. SWTP data shows the transition during March 1991.

4) The ADI feasibility study assumed that all but one blower would be shut down when the aerobic digesters were eliminated. As the new system was being started up, other treatment plant equipment in addition to the aerobic digesters were identified which operate on the same air the blowers provided to the digesters. Their demand for air has required that two blowers continue to 
run instead of only one. Plant personnel will have to be trained to optimize or eliminate superfluous air usage by this equipment to achieve the one blower operation predicted in the study. This process may take several months.

5) The biogas system suffered typical start-up problems which had to be corrected. One example involved water drainage problems magnified by the flooding conditions in January and February. Improper cover tension resulted in water accumulation which caused tears in the cover seams. The construction firm worked with plant personnel to correct these problems.

PHASE 2 ANALYSIS - BIOGAS UTILIZATION

The ADI feasibility study recommended implementation of the biogas recovery system and then an evaluation of whether the biogas should be sold or used by the city to generate electricity. The recovery system is now installed and the city is monitoring its performance. The utilization of the biogas is now under review, but no decision has been made as to whether the city will sell or use the biogas. Several factors affecting this decision have changed since the original study.

\section{Option 1: Sell Biogas}

In 1987, Kimberly-Clark (KC) expressed an interest in purchasing the excess biogas. If this option were selected, the city would deliver the biogas to the edge of $\mathrm{KC}$ 's property through approximately one mile of piping. 
Kimberly-Clark would be responsible for installing the remainder of the biogas line.

When the feasibility study was conducted in 1987 , the average natural gas cost to $\mathrm{KC}$ was $\$ 2.25$ per million BTU. The revenue potential from the sale of biogas was calculated as follows:

$$
\begin{aligned}
\text { Revenue }= & \$ 2.25 / \mathrm{MMBTU} * 0.8 * 5.6 * 10^{6} \mathrm{ft}^{3} / \mathrm{Yr} * 0.945 \\
& \star 600 \mathrm{BTU} / \mathrm{ft}^{3} \\
= & \$ 571,500 / \mathrm{Yr}
\end{aligned}
$$

where

$0.8=$ discount rate below market, value to stimulate interest by customer

$5.6 * 10^{6}=$ annual biogas production minus incinerator consumption

$0.945=$ availability and reduced heat value of saturated biogas

$600 \mathrm{BTU} / \mathrm{ft}^{3}=$ typical heat value of biogas

The construction of the pipeline to $\mathrm{KC}$, the associated controls and boiler modifications were estimated to cost $\$ 1,370,000$. Expected operation and maintenance costs for the pipeline system were $\$ 25,000$ per year. Hence, the original incremental payback for the biogas sale option would be 2.5 years.

Payback $=\$ 1,370,000 /(\$ 571,500-\$ 25,000)=2.5$ years

Since the study in 1987, natural gas prices in Memphis have fallen to record lows. The average natural gas price from July 1990 to June 1991 was $\$ 1.75$ per million BTU. This changes the revenue potential for the project considerably. 


$$
\begin{aligned}
\text { Revenue }= & \$ 1.75 / \mathrm{MMBTU} * 0.8 * 5.6 * 10^{6} \mathrm{ft}^{3} / \mathrm{yr} * 0.945 \\
& * 600 \mathrm{BTU} / \mathrm{ft}^{3} \\
= & \$ 444,500 / \mathrm{Yr}
\end{aligned}
$$

Assuming the original implementation cost estimate and operations and maintenance costs, the incremental payback for this option has changed to 3.3 years.

$$
\text { Payback }=\$ 1,370,000 /(\$ 444,500-\$ 25,000)=3.3 \text { years }
$$

\section{option 2: Generate Electricity on-site}

As a second alternative. the biogas could be used to generate electricity for use at the treatment plant to help reduce demand charges. Three 1,500 kilowatt (kW) generators would be located in a building near the sludge lagoons. The excess biogas is sufficient to fuel two generators at the same time. The third generator would be used when one of the other generators is down for maintenance or repairs.

When the SWTP changed to the ESP electricity rate schedule, the economics of generating electricity from the biogas also changed. The ESP rate offers electricity at a price approximately 13 percent less than the general service rate assumed in the preliminary study.

In the original study $A D I$ International estimated the SWTP would save $\$ 1,054,00$ per year by installing biogas-fueled generators to avoid purchasing electricity from the utility. The capital cost for the investment was $\$ 2,900,000$ and the annual maintenance costs were to be $\$ 155,000$. These figures represent an incremental payback of 3.2 years. 
Under the new ESP rate, the estimated savings are 13 percent less or $\$ 916,980$ per year. Assuming the same capital costs and annual maintenance costs, the revised incremental payback is 3.8 years.

\section{Phase 2 status}

Kimberly-clark has recently expressed interest in reviving the biogas pipeline project sometime in the future. However, the erratic behavior of the natural gas market and the record low prices this year have delayed further action.

The electricity generation option has also received increased interest in the wake of TVA'S ESP electric rates. TVA has revised the ESP rate schedule to include several new classifications of customers. The revised ESP rate schedule establishes a load curtailment priority based on the new classifications. This priority structure identifies the order in which customers are interrupted. Customers who can interrupt operations more often receive greater cost savings on electricity.

The new ESP program has been adopted by TVA, but the full range of options have not been clarified. Memphis Public Works is very interested in adding the SWTP to the new program. Greater cost savings appear to be available if the SWTP can withstand more frequent interruptions. These developments have recently encouraged significant interest in option 2: electricity generation using biogas. By constructing an electricity generation facility on-site, the SWTP can reduce its dependency on TVA and the impact of power service interruption and increase its potential for taking advantage of the new ESP options. 
CHAPTER FOUR -- CONCLNSIONS

\section{LESSONS LEARNED}

Review of Volume 1

The city of Memphis has gained valuable experience during the course of this project. The lessons learned from Volume 1 are summarized below.

* The success of an innovative, municipal project is officials/administrators.

The Public Works Division included the Memphis City Council in the project from its inception. Keeping the decision-makers informed allowed the project to progress rapidly through the legislative process.

* Technology transfer between the private and public sectors benefits both parties.

The City of Memphis will obviously benefit from this new technology primarily through tremendous savings in utility costs. The project designers and material manufacturers benefit from the successful application of their product in a municipal wastewater treatment system. other cities have wastewater treatment systems similar to 
the one in Memphis. These governments will naturally be interested in the project results. Memphis also offers a convenient central location for potential customers to experience the technology at work.

* Effective planning and integration of related projects may result in additional cost savings.

The City of Memphis selected a site adjacent to the sludge lagoons to locate a new patheological incinerator in order to utilize the biogas as fuel.

* Coordination between governmental agencies fosters enhanced communication and the cooperative effort essential for successful, municipal projects.

The Public Works Division was primarily responsible for the project:; however, several divisions participated in the coordination of financing and documenting the project.

Lessons From the Construction Phase.

The construction portion of Phase 1 generated lessons concerning the proper installation of the new equipment and the value of good construction management. Although many of the problems encountered were very site-specific, there were several general lessons learned which may be applied to similar cover applications.

* The feasibility study, project design, and project construction are each separate, essential steps in implementing a major project.

This may seem to be an incredibly simple observation, but many times these common sense steps are overlooked for an instant solution. This project took roughly four years to 
mature from the study phase to complete construction. During each phase of the project, new problems or concerns were identified and resolved. As in most construction projects, the scope was modified and details redesigned to respond to site conditions.

It is beneficial for municipalities to evaluate project economics between phases as the project develops to guarantee that the initial assumptions or projections are verified by actual experience. It is also critical that the external environment for the project be continuously monitored. The market price of natural gas dropped almost 25 percent during the course of this biogas recovery project. The SWTP also switched electricity rate schedules thereby lowering their unit cost of electricity by over 30 percent. Although these changes in energy costs did not eliminate the Phase 2 options, they significantly lengthened the payback periods. Fluctuating market conditions make it difficult to project long term benefits, so it is best to reassess the project as economic factors change.

* Prepare a project schedule with flexibility to allow
for delays.

Memphis has a wetter climate than any other location where a biogas recovery cover system is in operation. Record rainfall amounts in January and February 1991 caused huge water pockets to develop on top of the cover before installation was complete. These water pockets caused tears at the cover seams ADI personnel remained on-site to instruct treatment plant personnel on cover repair. The SWTP now has a staff of six to eight men capable of patching cover punctures. The water removal system is now fully functional, but several weeks were required for the repairs. 
The damage caused by the record rainfall proved thai the choice of cover material was best for the climate in Memphis. The alternative would also have sustained damage, however it could not have been repaired on site. choosing the alternative cover material would have been detrimental to the project.

In March, lightning during a severe thunderstorm damaged several biogas cover sensors which forced the recovery equipment to shut down. It took time to replace the sensors and install protective equipment. This unfortunate incident did, however, prove that the emergency venting system operated properly.

\footnotetext{
* Thorough testing of the biogas source improves the accuracy of savings estimations and may reduce the project implementation costs.
}

ADI International underestimated the insulating properties of the scum layer. Scum is the fraction of organic material in wastewater which is comprised largely of fats. These fats float to the top of the sludge lagoons to form an insulating layer over the sludge. This scum layer has proved to be such an effective insulator that the cover insulation may not have been required. Omitting the cover insulation would have reduced the construction cost by several hundred thousand dollars.

Problems with the biogas recovery system have not permitted an adequate monitoring period of normal operation; but, biogas production data gathered to date indicate a generation rate less than the feasibility study assumption. As system fluctuations level out, the biogas production rate should increase to assumed rates. Otherwise, the phase 2 alternatives may no longer be economically feasible. 
* Optimizing plant operation to achieve the full impact of the system conversion may take months or even years.

The bulk of the energy savings resulting from this project comes from reducing the number of large aeration blowers required to provide low pressure air to the aeration tanks. The feasibility study assumed the entire capacity of one aeration blower would be eliminated from the process. While the SWTP personnel have significantly reduced the air flow to the aeration tanks, they have not as yet achieved the predicted reduction. SWTP operators continue to experiment with lower air flows while maintaining the stability of the decomposition process to achieve the remaining energy savings.

* Both the public and private sectors gained technical expertise from these innovative projects.

Innovative construction projects offer an excellent opportunity to improve the technical expertise of local government personnel. In working with the design engineers and construction firm, Public Works personnel had to refresh their knowledge of all SWTP processes. By adapting the new technology to the plant, the plant operators became more familiar with the capabilities of the equipment and the treatment process. In addition, this project exposed the Public Works Division to state-of-the-art technology for wastewater treatment facilities. Also, local government has become more receptive to innovation in energy management.

The engineering and construction firms have both gained wisdom from this new application of the cover material. since this was the largest cover system constructed to date, special consideration of the physical aspects of 
installation had to be incorporated into the design. Both firms also gained experience in dealing with a municipality. Their experience should benefit them almost immediately since inquiries have already been received for similar applications in other states and overseas. 
REFERENCES

ADI International Inc. Feasibility Investigation on covering Sludge Storage Lagoons and Biogas Recovery and Utilization at the Memphis North Wastewater Treatment Plant. Memphis, Tennessee: 1988 .

Blake, Donald R. and F. Sherwood Rowland, "Continuing Worldwide Increase in Trophospheric Methane - 1978 to 1987," Science, Vol. 239, March 4,1988, pp. 1129-1131.

City of Memphis, Department of Environmental Engineering Annual Report 1986-1987, Meinphis, Tennessee, 1987.

Department of Planning, office of Supervisor of Public Utilities, City of San Antonio, Texas, Landfill Gas Recovery: A Methodology for Site Planning, Energy Task Force of the Urban Consortium, 1984.

Georgia Tech Research Institute, Biogas Utilization Handbook, Atlanta, Georgia, 1988.

Houghton, Richard A., Woodwell, George M., "Global climatic Change," Scientific American, Vol. 260, No. 4, April 1989, pp. $36-44$.

Ramanathan, V., "The Greenhouse Theory of climate changes: A Test by an Inadvertent Global Experiment," Science, Vol. 240, April 4, 1984, pp. 1129-1131.

Subcommittee of operation of Wastewater Treatment Plants, Water Polution Control Federation, operation of Wastewater Treatment Plants, WPCF Manual for Practice No. 11, Washington, D.C., 1970. 
Urban Consortium Energy Task Force. Environmental Services Division, Denver, Colorado. Alternative Uses for Digester Methane Gas: An Analysis of Technical and Economic Feasibility, 1983.

U.S. Environmental Protection Agency, Municipal Environmental Research Laboratory, office of Research and Development, Process Design Manual for sludge Treatment and Disposal, Report EPA 625/1-79-011, September 1979. 
REPORT AND INFORMATION SOURCES

Additional copies of this report, "sludge storage Lagoon

Biogas Recovery and Use", are available from:

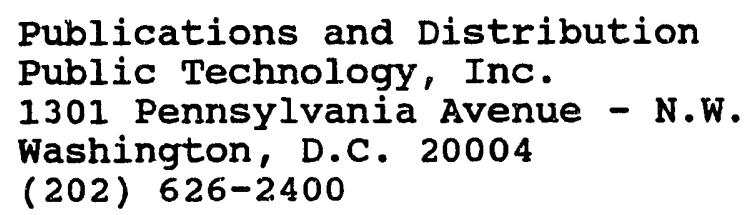

Further information regarding the project discussed in this report is available from:

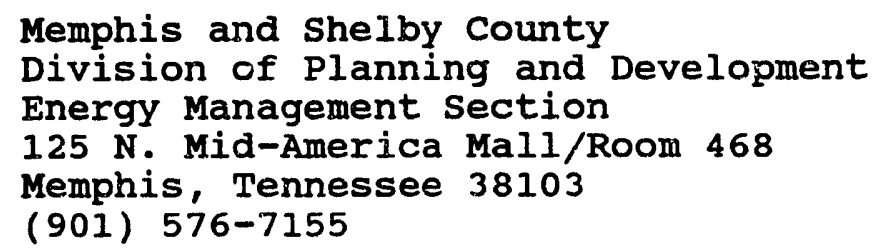

Publication order No.: 


\section{Publications Price List - UCETF Reports}

ITEM

79-300 Planning for and Purchasing Computer Technology

81-301 Energy Management and Technology for Urban Government

81-303 Municipal Energy Management

81-304 Development of Local Energy Management Prepardness

81-309 Energy Management. The Public Sector

81-310 Simplified Methodology for Community Energy Management

81-311 Developing Energy Emergency Prepardnes

81-312 Energy Emergency Operations Plan: A Project Report

81-314 Vehicle Fuel Emergency Prepardness: A Project Report

81-317 Energy Efficient Vehicle Fleet Management and Procurement Guide

81-319 Variable Air Volume System

$81-320$

81-324

$81-327$

$82-302$

$82-303$

82-305

$82-307$

82-311

$82-313$

$82-315$

$82-317$

83-302

83-303

83-304

83-305

83-31

83-314

83-318

83-319

$$
\text { Variable Air Volume System }
$$

Energy Data Gathering, Analysis, and Review System Energy Management for Small Business

Development of a Hydrogen-Fueled Mass Transit Vehicle

Public Housing Energy Efficiency Through Private Financing

Energy Economic Development

Development of an Energy Action Plan: Participating Approach

Strategies to Improve Community Energy Use Practices

Commercialization of Fluidized-Bed Combustion

Energy Conservation and Economic Development

Reducing Regulatory and Financial Impediments to Energy Conservation

Microcompter Tools for Trans. and Residntl Energy Conservation

Energy Financing for Local Governments

Improving Energy Mgmt and Accountability in Municipal Operations

Telecommunications in Local Governments

Multi-Jurisdictional Planning for District Heating and Cooling

Energy Conservation Through Computerized Automation

Memphis Area Rideshare On-Line Information System

Developing Sources and Techniques for Alternative Financing of Energy

The Rehabilitation and Retrofit of Older Houses to Superinsulated Standards

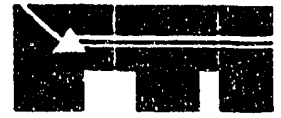

PRICE

6.50

15.00

10.00

10.00

15.00

20.00

15.00

15.00

10.00

15.00

15.00

20.00

10.00

15.00

10.00

20.00

15.00

10.00

15.00

10.00

20.00

20.00

15.00

15.00

15.00

10.00

18.00

18.00

20.00

15.00 


\begin{tabular}{|c|c|c|}
\hline ITEM & $\begin{array}{l}\text { Publications Price List - UCETF Reports } \\
\begin{array}{l}\# \\
\text { TITLE }\end{array}\end{array}$ & PRICE \\
\hline 84-301 & Coordinating Preventive Maintenance with Energy Management & 15.00 \\
\hline $84-303$ & Innovative Finance Plans for Privately Owned Waste/ Vol. 1 & 15.00 \\
\hline $84-304$ & Innovative Finance Plans for Privately Owned Waste/Vol. 2 & 15.00 \\
\hline 84-305 & Computer Based Maintenance & 15.00 \\
\hline $84-306$ & Analysis of Municipal Bus Operations for the Advancement of Fuel Cell & 15.00 \\
\hline $84-309$ & Central Energy Systems Applications to Economic Development & 20.00 \\
\hline $84-311$ & Feasibility of Water-Based District Heating and Cooling & 15.00 \\
\hline $84-312$ & Implementation Methods for an Integrated Energy System & 10.00 \\
\hline $84-314$ & Application of Mini-Van Technology to Vanpool Services & 18.00 \\
\hline $84-315$ & Facilities Energy Monitoring System & 15.00 \\
\hline $84-320$ & Development of Computerized Inventory and Maintenance System for Municipal & 15.00 \\
\hline $84-321$ & Hydrate Process for Waste Water Treatment Plant Sludge Dewatering & 15.00 \\
\hline $84-322$ & Energy Management and Technoingy for Urban Governments & 15.00 \\
\hline 85-307 & Thermal Storage Strategies for Energy Cost Reduction & 18.00 \\
\hline $85-312$ & Shared Savings and Low Income Homeowners & 18.00 \\
\hline $85-314$ & Alternative Techniques for Dev. of Energy Efficient Residences & 15.00 \\
\hline $85-316$ & Modular District Heating Planning as a Development Tool & 15.00 \\
\hline 85-319 & District Heating In Denmark & 10.00 \\
\hline $85-320$ & Transportation Management for Business Relocation & 15.00 \\
\hline $85-322$ & Retention and Expansion Program for High Energy Use & 15.00 \\
\hline 23 & Energy Monitoring and Controlling in Municipal Facilities & 10.00 \\
\hline-26 & Resource Recovery for Urab Yard Waste & 18.00 \\
\hline $86-301$ & On-Site Municipal Fuel Cell Power Plan : Feasibility and Application Guide & 15.00 \\
\hline $86-302$ & Neighborhood Energy Efficiency \& Reinvestment & 15.00 \\
\hline $86-304$ & Technology Transfer for Residential Energy Efficiency & 15.00 \\
\hline $86-305$ & Technology Transfer for Residential Energy Programs in New Construction and & 15.00 \\
\hline $86-306$ & District Heating Marketing: Analysis of a Twelve City Survey & 20.00 \\
\hline $86-307$ & Disposal Techniques with Energy Recovery for Scrapped Vehicle Tires & 20.00 \\
\hline $86-310$ & Hidden Link: Energy and Economic Development, Phase I & 15.00 \\
\hline $86-311$ & High Efficiency Gas Furnace Modification in Low Income Housing & 15.00 \\
\hline
\end{tabular}


Publications Price List - UCETF Reports

\begin{tabular}{|c|c|c|}
\hline ITEM & TITLE & PRICE \\
\hline $86-312$ & Energy Cost Reduction Through Wastewater Flow Equalization & 20.00 \\
\hline $86-313$ & Water Supply System Energy Conservation Through Computer Control & 18.00 \\
\hline $86-314$ & Inhibition of Respiration in Activated Sludge by High Carbon Dioxide & 7.50 \\
\hline $86-315$ & Balancing Single Pipe Steam Heating Sytems & 20.00 \\
\hline $87-301$ & HVAC Equipment Replacement for Best Size \& Efficiency & 20.00 \\
\hline $87-305$ & Energy Enhancement in New Residential Construction & 40.00 \\
\hline $87-306$ & Intergrating Energy Efficiency into Mun. Purchasing Decisions & 20.00 \\
\hline $87-307$ & Municipal Underground Storage Tanks: An Energy Manager's Guide & 18.00 \\
\hline $87-311$ & Electric Utility Franchise Guide & 20.00 \\
\hline $87-312$ & Economic Development Through Energy Technology Tranfer & 15.00 \\
\hline $87-313$ & Computer Assisted Control for Municipal Water Systems, Phase II & 20.00 \\
\hline $87-317$ & Joint City Government/Utility Partnerships to Keduce Business Costs & 15.00 \\
\hline $87-321$ & Evaluating the Options for a Modern Integrated Energy System in a Large & 15.00 \\
\hline $87-322$ & Electric Utility Franchise Expiration and Renewal Process & 15.00 \\
\hline $87-324$ & Memphis Area Rideshare & 15.00 \\
\hline $87-327$ & Energy Effiecient Urban Cooling Technologies: 1st National Conf. & 20.00 \\
\hline $88-302$ & Direct Digital Control of Air Washer Coolong System & 15.00 \\
\hline $88-303$ & Energy Efficient Building Design: Guidelines for Local Government & 15.00 \\
\hline $88-304$ & Energy Master Planning: Innovative Design and Energy Analysis Services for & 22.00 \\
\hline $88-305$ & Cogeneration and Cooling in Small Scale Applications & 15.00 \\
\hline $88-306$ & HVAC Equipment Replacement for Best Size and Efficiency, Tansfer Report & 15.00 \\
\hline 88-308 & Conversion of Resource Recovery Steam to Hot and Chilled Water Systerns & 10.00 \\
\hline $88-309$ & Energy Planning for Economic Development & 18.00 \\
\hline $88-310$ & The Earth-Coupled Heat Pump: Utilizing Innovative Technology in Single & 15.00 \\
\hline $88-316$ & Household Hazardous Waste Management Planning & 15.00 \\
\hline $88-317$ & Hazardous Waste as an Energy Manager's Issue & 15.00 \\
\hline $88-318$ & Household Hazardous Waste: Implementation of a Pern nent Collection & 20.00 \\
\hline $88-319$ & Integrating Energy Efficiency Into Municipal Purchasing Decisions: & 15.00 \\
\hline $88-322$ & Marketing Energy Efficiency Programs to Commercial and Industrial Firms: & 15.00 \\
\hline $89-303$ & Wastewater Treatment Process Energy Optimization & 13.00 \\
\hline
\end{tabular}




\section{Publications Price List - UCETF Reports}

\begin{tabular}{lll} 
ITEM \# & \multicolumn{1}{c}{ TITLE } & PRICE \\
\cline { 3 - 3 } $89-306$ & Reducing Electricity Demand Through Energy-Related Efficient Construction & 15.00 \\
\cline { 3 - 3 } $89-310$ & Sludge Storage Lagoon Biogas Recovery and Use, Volume 1 & 15.00 \\
$89-314$ & Communicating with the Public About Environmental Health Risks: A Case & 13.00 \\
$89-315$ & A Case Study in the Pursuit of Urban Energy Efficiency & 15.00 \\
\hline $89-330$ & Analysis of Programmatic Fleet Conversion to Ethanol Blends & 15.00
\end{tabular}



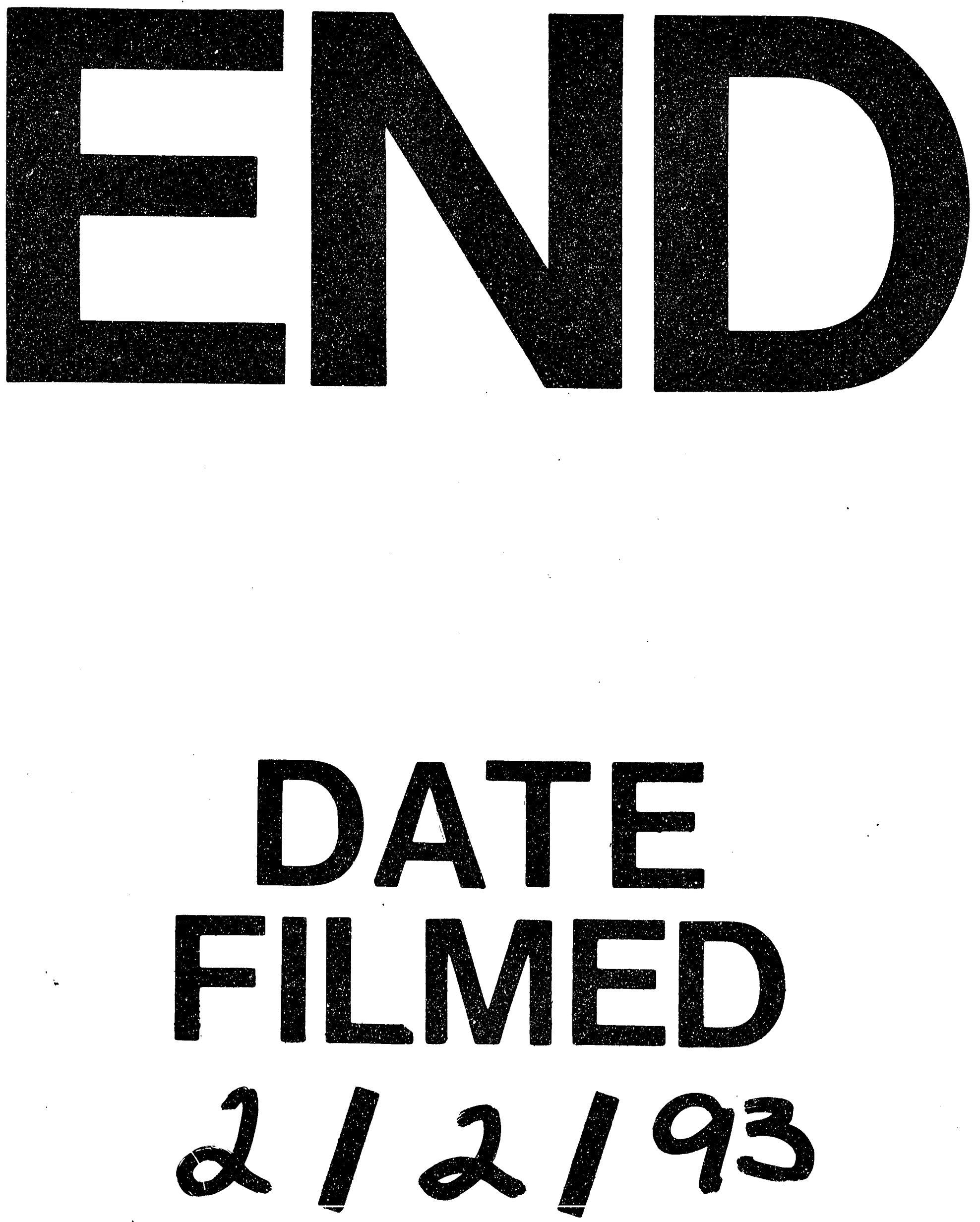
